\title{
The New Social Engineers in the Age of Obama: Black Corporate Lawyers and the Making of the First Black President
}

\section{Citation}

David B. Wilkins, The New Social Engineers in the Age of Obama: Black Corporate Lawyers and the Making of the First Black President, 53 Howard Law Journal 558 (2010).

\section{Published Version}

http://www.law.howard.edu/dictator/media/229/how_53_3.pdf

\section{Permanent link}

http://nrs.harvard.edu/urn-3:HUL.InstRepos:4886628

\section{Terms of Use}

This article was downloaded from Harvard University's DASH repository, and is made available under the terms and conditions applicable to Open Access Policy Articles, as set forth at http:// nrs.harvard.edu/urn-3:HUL.InstRepos:dash.current.terms-of-use\#OAP

\section{Share Your Story}

The Harvard community has made this article openly available. Please share how this access benefits you. Submit a story.

Accessibility 


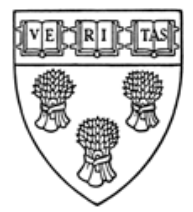

Harvard Law School

Public Law \& Legal Theory Working Paper Series

Paper No. 11-11

\title{
Rethinking the Public-Private \\ Distinction in Legal Ethics: The Case of "Substitute" Attorneys General
}

\author{
David B. Wilkins \\ Harvard Law School
}

This paper can be downloaded without charge from the Social Science

Research Network (SSRN) electronic library. 


\title{
RETHINKING THE PUBLIC- PRIVATE DISTINCTION IN LEGAL ETHICS: THE CASE OF "SUBSTITUTE" ATTORNEYS GENERAL
}

\author{
David B. Wilkins*
}

2010 MICH. ST. L. REV. 423

TABLE OF CONTENTS

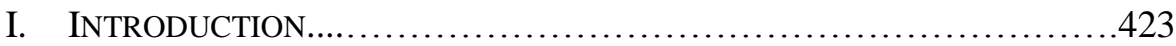

II. THE RISE OF “SUBSTITUTE” ATTORNEYS GENERAL ……...................428

III. SHOULD PRIVATE CONTINGENT FEE LAWYERS EXERCISE

PUBLIC POWER?. .434

IV. TOWARD A NEW MODEL OF THE PUBLIC-PRIVATE LAWYER .455

\section{INTRODUCTION}

By any measure, Frank J. Kelley was an extraordinary Attorney General. In his thirty-seven years in office, Mr. Kelly redefined the role of the state's chief legal officer, creating a model that has now been widely copied around the country. Under his leadership, the size of the office tripled, from 84 lawyers in 1962 to 301 attorneys when he retired in 1998. Kelley put these new resources to good use, creating the country's first Consumer Protection and Environmental Divisions and vigorously prosecuting a wide range of unfair business practices and environmental harms. ${ }^{1}$

* Lester Kissel Professor of Law, Vice Dean for Global Initiatives on the Legal Profession, and Faculty Director of the Program on the Legal Profession and the Center on Lawyers and the Professional Services Industry, Harvard Law School. This paper was initially given as the inaugural Frank J. Kelley Lecture at Michigan State University in September 2009. I want to thank Dean Howarth, Professors Troy Brown and Renee Knake, and the other faculty and students who attended that event for their insightful comments on the lecture as well as for their gracious hospitality. I also particularly want to thank Frank Kelley for his generous support of both the lecture series and of the Kelley Institute of Ethics that bears his name. He is a model for the synthesis of public and private responsibilities that I hope to describe in this piece. Kathleen Clark provided very helpful comments on an earlier draft, as well as access to her forthcoming papers on the ethical regulation of government contractors. Cory Way provided invaluable research and editorial assistance.

1. Elmer E. White, Michigan Lawyers in History-Frank J. Kelley: The Eternal General, 79 МicH. B.J. 688, 688, available at http://www.michbar.org/journal/article.cfm? articleID $=87 \&$ volumeID $=8$ (last visited Oct. 18, 2010). 
Attorney General Kelley's most lasting contribution, however, may have been the lesson that he taught his fellow AGs about how to utilize the antitrust laws and other civil causes of action to seek restitution and other forms of relief against corporations for harms allegedly inflicted on state citizens. As President of the National Association of Attorneys General, Kelley was instrumental in mobilizing his counterparts around the country to band together to use these potent tools to hold powerful corporations accountable. During his last years in office, this strategy culminated in the massive class action law suits filed by Kelley and other Attorneys General against the tobacco companies - litigation that resulted in a $\$ 12$ billion settlement for the state of Michigan, the largest in the state's history. ${ }^{2}$

Given his extraordinary accomplishments, it is unlikely that Frank Kelley's career will ever be duplicated in Michigan, or indeed anywhere else. This is not simply because of the personal and professional qualities that made the man who was affectionately known by his constituents as the state's "Eternal General" such a beloved figure with Michigan voters. ${ }^{3}$ Nor is it simply because Michigan now has term limits that would preclude even someone as extraordinary as Mr. Kelley from serving ten terms in office. Instead, the very structure of twenty-first century legal careers makes it very unlikely that more than a tiny handful of those graduating law school today will spend thirty-seven years in the same job-whether that job is in the public or the private sector. ${ }^{4}$

Indeed, today's young lawyers are increasingly likely to build careers that move between the public and the private sectors. Thus, in a ten-year nationwide study of lawyers who entered the bar in 2000, my colleagues and I determined that more than $50 \%$ of lawyers in our sample who changed jobs between 2003 and 2007 had also changed practice settings, for example moving from private practice to government or vice versa. ${ }^{5}$ The economic downturn in the private sector market that began in 2008 has only accelerated this trend, as many young lawyers are being offered financial and oth-

2. Id. at 689 .

3. Id. at 688 .

4. For example, in a nationwide survey of legal careers conducted in 2003, more than one third of all lawyers who entered the bar in 2000 had already changed jobs - and more than $44 \%$ were planning on changing jobs in the next two years. RONIT DINOVITZER, ET AL., AM. BAR Found. \& NALP Found. FOR LAW CAREER RESEARCH AND Educ., AFTER THE JD: First Results of A NATIONAL Study of Legal CAREERs 53 (2004). Four years later when we surveyed these lawyers again, the average number of jobs held by the entire sample was 2 - and almost two-thirds had changed jobs at least once since we surveyed them in 2003. Ronit DinOvitzer, ET AL., AM. BAR Found. \& NALP Found. FOR LAW CAREER Research and Educ., After the JD II: Second Results from a National Study of LEGAL CAREERS 54 (2009) [hereinafter AJDII].

5. See AJDII, supra note 4, at 54-60. Indeed about 50\% of lawyers who were working in the federal government in 2003 had switched to other practice settings by 2007 . Id. 
er incentives to begin their careers in the public sector before (hopefully) starting their private sector jobs as associates. ${ }^{6}$

Moreover, mobility is only one way in which the traditional boundaries between public and private sector careers have been blurring in recent years. Even lawyers who spend the bulk of their careers in either public or private sector roles are likely to find themselves in positions in which their duties and responsibilities straddle this traditional divide. As we found out from painful experience over the last few years, lawyers who represent important private institutions, such as banks and other financial intermediaries, play a crucial role in our public regulatory system. ${ }^{7}$ Indeed, after the 2008 meltdown, many of these institutions are now at least partially owned by taxpayers - which, of course, is just a dramatic illustration of the fact that deposit insurance and other forms of regulatory guarantees have always given the public an important de facto stake in these entities. ${ }^{8}$ As globalization increasingly forces companies to confront complex issues such as child labor, environmental protection, and economic development, the general counsels and outside firms that represent these important global players are recognizing that they must understand and incorporate a broad set of public norms and values if they are to perform these roles effectively. ${ }^{9}$ At the same time, the government lawyers who oversee these institutions find themselves in the position of being charged both with both ensuring that the private lawyers take adequate account of these public norms, and furthering government competitiveness policies that give the state a significant role in promoting private innovation and market penetration by US companies both at home and abroad. ${ }^{10}$

Finally, the growing use of "outsourcing" by all levels of government-including the express outsourcing of legal services-means that many ostensibly "private" lawyers now exercise de jure public authority in

6. See Nate Raymond, Deferred Associates Evaluate their Experience in Public Interest Jobs, N.Y. L.J., Mar. 8, 2010, available at http://www.law.com /jsp/article.jsp?id=1202445875118.

7. See generally John C. Coffee, JR., GatekeEPers: The Professions AND CORPORATE GOVERnANCE (2006).

8. See Steve Lohr, U.S. Investing $\$ 250$ Billion to Bolster Bank Industry, N.Y. TIMES, Oct. 14, 2008, at A1, available at http://www.nytimes.com/imagepages /2008/10/13/business/20081014_BAILOUT1_GRAPHIC.html (see the graphic summarizing the rescue plan and the largest recipients). For a discussion of the key role played by federal insurance in the banking business, see David B. Wilkins, Making Context Count: Regulating Lawyers After Kaye, Scholer, 66 S. CAL. L. ReV. 1145 (1993).

9. See Ben W. Heineman Jr. High Performance with High Integrity (Memo to the CEO) (2008) (discussing these and other similar examples and arguing that understanding and incorporating public norms is key to a corporation's long term success).

10. See Kathleen Clark, Government Lawyers and Confidentiality Norms, 85 WASH. U. L. REV. 1033, 1049-1073 (2007) (noting the multiple and often conflicting public and private responsibilities of government lawyers). 
areas ranging from contracting to litigation to regulatory counseling. ${ }^{11}$ These private lawyers now work alongside public lawyers to conduct what Frank Kelley called "the people's business." Similarly, private pro bono lawyers now provide more legal services to the poor than their state funded counterparts in the Legal Services Corporation. ${ }^{12}$

These developments arguably have important implications for the field of legal ethics. Specifically, how should lawyers in private practice incorporate public norms in the various contexts in which their roles implicitly or explicitly call on them to do so? How should lawyers for public entities account for the interests of private parties in promoting public policies that implicate these concerns? And, how should law schools prepare students for careers that are increasingly likely to include time in both public and private sector roles?

Clearly, these are large and difficult questions, and I certainly do not pretend that I will answer them here. Instead, in the remainder of this Essay I will simply try to highlight how the changes we are observing in legal practice problematize the standard conception of the public-private distinction that underlies much of the way we think about legal ethics. I will do so by examining the legacy of Frank Kelley's most enduring innovation: Attorneys General bringing suit to recover monetary damages and other relief from private companies for injuries allegedly inflicted on state citizens. In the years since Kelley pioneered such actions, lawsuits of this kind have become an increasingly important part of the work of many AG offices. Moreover, in prosecuting these actions, many of Kelley's successors have also followed another of his innovations: bringing in private attorneys to either supplement or supplant government lawyers in handling some or all of the work being done on the matter. Thus, in the Tobacco Litigation, Kelley brought in two prominent plaintiff class action law firms-Scruggs, Millette, Lawson, Bozeman \& Dent from Pascaloula Mississippi and Ness, Motley, Loadholt, Richardson \& Poole from Charleston South Carolina-to be "Special Assistant Attorneys General" to work alongside three lawyers from Kelley's newly created Environmental Division in prosecuting the case. In recent years, arrangements of this kind have become increasingly common. ${ }^{13}$ In Louisiana, for example, Attorney General Buddy Caldwell is seeking permission to hire private attorneys to handle litigation against BP and other defendants arising out of the recent Deep Water Horizon disas-

11. See Kathleen Clark, Ethics for an Outsourced Government (January 19, 2011) (unpublished manuscript) (on file with author).

12. See, e.g., Scott L. Cummings, The Politics of Pro Bono, 52 UCLA L. REV. 1, 1 (2004).

13. See infra notes $27-30$ and accompanying text. 
ter. ${ }^{14}$ Given both shrinking state budgets and the growing list of potential big-ticket claims involving alleged harms to consumers or the environment, the number of Attorneys General seeking to create arrangements of this kind will, in all likelihood, only increase.

So too, however, will the controversy surrounding this practice. When Frank Kelley hired Richard "Dickey" Scruggs and Ronald Motley to prosecute tobacco companies in Michigan in 1995, he was promptly greeted by a motion by the various defendants in the case to disqualify his new Special Attorneys General. Specifically, the tobacco defendants argued that Kelley did not have the statutory or constitutional authority to delegate his public duties to these private parties, particularly given that the lawyers were not being paid either a government salary or an hourly fee but rather an amount that would be determined by the court based largely on the recovery they obtained for the state. ${ }^{15}$ Kelley was able to defeat this effort, as have most - although not all —of the Attorneys General who have followed this path. But as a decision by the California Supreme Court in a similar case in July 2010 makes clear, the issue continues to be actively litigated and hotly contested. ${ }^{16}$ The fact that Scruggs was subsequently convicted of conspiracy to bribe a judge in Mississippi in an attempt to secure a larger share of a $\$ 26$ million fee in a class action involving claims arising out of Hurricane Katrina has only fanned the flames. ${ }^{17}$

14. Bill Barrow, House Committee Approves Hiring Lawyers for Gulf Oil Spill Cases, Times-Picayune, June 15, 2010, available at http://www.nola.com/news/gulf-oilspill/index.ssf/2010/06/house_committee_approves_hirin.html. Although the legislature adjourned without reaching a final vote on the matter, Louisiana Governor Bobby Jindal has vowed to ensure that Caldwell has "the tools he needs" to protect the state's interest. Bill Barrow, Attorney General Buddy Caldwell's Office to Receive Another \$5 Million of BP Grant, Jindal Says, TIMES-PICAYUNE, June 23, 2010, available at http://www.nola.com/news/gulf-oil.spill/index.ssf/2010/06/attorney_general_buddy_caldwel _2.html [hereinafter Caldwell's Office to Receive Another \$5 Million].

15. Brief for Plaintiff at 6 Kelley ex rel. Michigan v. Philip Morris, Inc. (Mich. Cir. Ct. Ingham Cnty.) (1996) (No. 96-84281-CZ) (on file with author).

16. See Cnty. of Santa Clara v. Superior Court, 235 P.3d 21 (Cal. 2010). The U.S. Supreme Court recently denied cert in the case, but as the public reaction to the decision suggests, this is unlikely to bring an end to the controversy. See Abigail Rubenstein, High Court Won't Hear Calif. Contingency Fee Case, Law 360, Jan. 12, 2011, available at http:// www.law360.com/web/articles/219214.

17. See Abha Bhattarai, Class-Action Lawyer Given 5 Years in a Bribery Case, N.Y. TIMES, June 28, 2008, at C3, available at http://www.nytimes.com/2008/06/28/business /28tort.html?_r=2\&sq=scruggs\&st=nyt\&adxnnl=1\&oref=slogin\&scp=1\&adxnnlx=12147475 06-am4UNsWZJnsR/wM7NemCvA. Not surprisingly, the additional fact that a federal judge publicly accused Scruggs of conspiring with the Attorney General of Mississippi to skirt a court order issued in a related case requiring the return of documents that the Attorney General believed demonstrated that the same insurance company Scruggs was suing in the private class action had committed fraud against policyholders in the state has only added to the controversy. See Jay Reeves, Federal Judge: Mississippi Attorney General Conspired with Trial Lawyer, Ins. J., June 9, 2008, available at http://www.insurancejournal 
In the pages that follow, I will not try to adjudicate the merits of this dispute between supporters and opponents of deputizing private lawyers to pursue public claims against private defendants. Instead, consistent with my overall theme, I will use the dispute over the hiring of what my colleague William Rubenstein has helpfully labeled as "substitute" private attorneys general to elaborate some of the issues raised by the increasing blurring of public and private lawyering roles and to suggest some ways that the profession and the public might respond to these challenges. ${ }^{18}$

The rest of my argument proceeds in three parts. Part II charts the rise of the use of substitute attorneys general following Frank Kelley's pioneering efforts in the Tobacco Litigation. Part III then presents the objections that have been raised to this practice and suggests that while these objections appear unlikely to persuade either politicians or fair minded observers to abandon the use of private lawyers to augment state enforcement resources, the critics do underscore the need for policymakers and lawyers to address the growing complexity of the responsibilities of both public and private lawyers in this area. Part IV concludes with some brief observations about what it will take for the profession to create a set of institutional arrangements and ethical norms capable of defining and reinforcing a workable set of understandings for how lawyers should conceptualize and discharge their public and private responsibilities in particular lawyering contexts.

\section{II.THE RISE OF “SUBSTITUTE” ATTORNEYS GENERAL}

Frank Kelley certainly did not invent the idea of hiring private lawyers to represent the government's interest in specific proceedings. At least since Brown v. Board of Education, public lawyers have brought in legal heavy weights to argue important cases in the United States Supreme Court and in other high stakes proceedings. ${ }^{19}$ In 1997, for example, the United

.com/news/southeast/2008/06/09/90752.htm. I return to the fact that documents discovered in private litigation may be used to support public causes of action brought by Attorneys General-and that documents discovered in public actions often fuel private "coattail" class action litigation-below.

18. See William B. Rubenstein, On What a "Private Attorney General" is-and Why it Matters, 57 VAND. L. REV. 2129, 2143-55 (2004) (distinguishing "substitute" private attorneys general who - at least in theory - "perform the exact functions of the attorney general's office" from either "supplemental" private attorneys general, who bring private litigation to vindicate public rights, and "simulated" private attorneys general, whose actions on behalf of a private party generate a common fund that benefits other private parties). I return to Rubenstein's helpful analysis below.

19. See Richard Kluger, Simple Justice: The History of Brown v. BoArd of Education AND Black AmericA's Struggle for Equality 529-31 (Vintage Books ed., 2004) (1975) (describing how the state of South Carolina hired John W. Davis, former U.S. Solicitor General and founder of the Wall Street law firm of Davis, Polk, Wardwell, Sunder- 
States Department of Justice hired famed litigator David Boies to try the government's antitrust case against Microsoft. ${ }^{20}$ In addition, state officials sometimes retain private counsel even when they are being sued in their official capacity. ${ }^{21}$ On other occasions, public lawyers bring in "special prosecutors" to investigate and prosecute public officials accused of wrongdoing in circumstances where the impartiality of a similar investigation by public lawyers might legitimately be called into question..$^{22}$ Indeed, in many small towns it is not uncommon for many governmental lawyering functions to be performed by private attorneys acting on a part-time basis.

These typical practices, however, differ from what Kelley and his fellow Attorneys General did in the Tobacco Litigation in two related respects. First, unlike most of the instances where private attorneys have traditionally been used, the Tobacco cases sought to recover monetary damages from private companies on the basis of torts that the defendants allegedly committed against the state's citizens. Thus, in the Tobacco cases, the states argued that cigarette manufacturers should be held liable for all of the costs that state governments were forced to expend paying for the harms inflicted on their residents as a result of smoking. ${ }^{23}$ Although damages are certainly possible in antitrust actions such as the one at issue in the Microsoft litigation, as Professor Howard Erichson notes, "the role of collecting money damages for antitrust harm has more commonly fallen to private plain-

land \& Kiendl to defend "separate but equal" in the famous Supreme Court case). According to Kluger, the state "turned the case over to Davis without any strings attached." Id. at 545. I return to the question of control below.

20. Howard M. Erichson, Coattail Class Actions: Reflections on Microsoft, Tobacco, and the Mixing of Public and Private Lawyering in Mass Litigation, 34 U.C. DAVIS L. REV. 1, 17 (2000). Indeed, as Jack Coffee points out, after some states refused to accept the settlement between Microsoft and the government at the end of the liability stage, both the objectors and the government hired high profile private lawyers to represent their respective interests in the litigation over whether the agreement should be upheld. John C. Coffee, Jr., "When Smoke Gets in Your Eyes": Myth and Reality About the Synthesis of Private Counsel and Public Client, 51 DePAul L. REV. 241, 242-43 (2001) (describing how California hired Brendan Sullivan from Williams \& Connolly to challenge the settlement, while the federal government brought in Phillip Beck from Bartlit, Beck, Herman, Palenchar \& Scott to defend it). Ironically, two years later Boies and Beck would square off in litigation culminating in the Supreme Court's consideration of Bush v. Gore, 531 U.S. 98 (2000), arguably the most important Supreme Court case since Brown v. Board of Education, in which both represented public officials claiming that they were entitled to occupy the highest office in the land.

21. See Nanette Asimov \& Lance Williams, Gov. Davis vs. Schoolkids-High Priced Legal Team Browbeats Youths About Shoddy Schools, S. F. Chron, Sept. 2, 2001, at A1 (describing how California Governor Gray Davis hired the law firm of O'Melveny \& Meyers to defend him against a law suit challenging the conditions in California schools).

22. See Rubenstein, supra note 18, at 2143 (discussing the federal special prosecutor statute).

23. Richard A. Daynard \& Graham E. Kelder Jr., The Many Virtues of Tobacco Litigation: In the Failed Global Settlement, the Tobacco Industry Almost Freed Itself from the Civil Justice System, Trial, Nov. 1998, at 34 (describing the cause of action). 
tiffs. ${ }^{24}$ Second, unlike most of the attorneys in the cases described above, the lawyers engaged in the Tobacco Litigation were neither paid a government salary nor an hourly fee. ${ }^{25}$ Instead, to varying degrees the lawyers hired by Frank Kelley and other Attorneys General were paid a fee that was heavily contingent on the size of the recovery that they generated in the case. $^{26}$

In the years following the record-breaking Tobacco settlements, both of these aspects have become increasingly common in cases in which private lawyers have been brought in to conduct litigation against private parties. Just two years after Frank Kelley and his fellow Attorneys General settled the Tobacco Litigation, several states and municipalities filed law suits against gun manufacturers and other related parties alleging theories about the recoupment of medical and other expenses similar to those asserted in the Tobacco Litigation. ${ }^{27}$ Similar actions, involving similar theories, have been filed against the manufacturers of lead paint, HMOs and other health care providers, brewers and distillers, fast food chains, and in the years since the housing market crash, mortgage lenders. ${ }^{28}$ In many-

24. Erichson, supra note 20, at 19. Indeed, in the Microsoft case itself, the government primarily sought various forms of injunctive relief, including the break-up of the company. See Massachusetts ex rel. v. Microsoft Corp., 373 F.3d 1199, 1204-05 (D.C. Cir. 2004) (reporting that " $[\mathrm{t}]$ he two complaints ... sought various forms of relief, including an injunction against certain of Microsoft's business practices").

25. In the Microsoft case, for example, the Justice Department paid Daivd Boies a reduced hourly fee of $\$ 250$ per hour-down significantly from the $\$ 600$ an hour he typically charged his private clients while at Cravath. See Elisabeth Bumiller, Readying the Slingshot for a Modern Goliath, N.Y. TimES, June 12, 1998, at B2.

26. I return to the question of whether it matters if the fee is entirely contingent or, as is more commonly the case, the product of some form of arbitration or judicial determination. Nevertheless, it is fair to say that in most of these cases "the lawyers would have received nothing had there been no recovery, and the amounts were driven largely by the size of the recovery." Erichson, supra note 20, at 18.

27. See Howard M. Erichson, Private Lawyers, Public Lawsuits: Plaintiffs' Attorneys in Municipal Gun Litigation, in SuIng THE Gun Industry: A BattLe at the Crossroads of Gun Control And Mass Torts 129, 138-39 (Timothy D. Lytton, ed., 2005).

28. See, e.g., Adam Liptak, A Deal for the Public: If You Win, You Lose, N.Y. Times, July 9, 2007, at A10 (describing several pollution cases); Walter Olson, Op-Ed, Tort Travesty, WALL ST. J., May 18, 2007, at A17 (reporting that "trial lawyers representing public clients on contingency fee are suing businesses for billions over matters as diverse as prescription drug pricing, natural gas royalties and the calculation of back tax bills"); Cnty. of Santa Clara v. Superior Court, 235 P.3d 25, 25 (Cal. 2010) (reporting that the litigation concerns "[a] group of public entities . . p prosecuting a public-nuisance action against numerous businesses that manufactured lead paint"); Erichson, supra note 20, at 20-21 (describing actual and potential litigation against other industries); E. Scott Reckard, Countrywide Sued by State Over Lending, L.A. TIMES, June 26, 2008, at C1, available at http://articles.latimes.com/2008/jun/26/business/fi-country26 (describing California's suit against Countrywide). 
although certainly not all —of these cases, private lawyers have played a key role. Indeed, many of these actions have been brought by the same lawyers who prosecuted the Tobacco cases, who were once again deputized as special attorneys general for this purpose. ${ }^{29}$ And, like the lawyers Frank Kelley retained in Tobacco, many of these lawyers are being paid on the basis of fees that are substantially contingent on the outcome of the case. ${ }^{30}$ As indicated above, the litigation that will inevitably follow the BP disaster may very well take a similar course.

A number of factors are driving these developments. First and foremost is money. Not surprisingly, most of the consumer, environmental, and regulatory actions brought by states in recent years involve large companies accused of causing widespread harm. ${ }^{31}$ As a result, the defendants in these cases have deep pockets and are capable of hiring the best legal talent money can buy to wear down their opponents, even when that opponent is the state. As Frank Kelley was quick to point out in the opening section of his brief in opposition to the Tobacco defendants' efforts to disqualify the private attorneys he brought in to prosecute the case, "[i]t is no secret that the Defendants have mustered an army of the nation's largest law firms, which include hundreds of attorneys, to fight a scorched-earth war." 32 As a result,

29. See Erichson, supra note 27, at 137-38 (reporting that Wendell Gauthier and a group of lawyers known as the Castano Group for their role in the Tobacco Litigation played a key role in several law suits by municipalities against gun manufacturers).

30. See Cnty. of Santa Clara, 235 P.3d at 36; see, e.g., Erichson, supra note 27, at 137 (reporting that "New Orleans retained the Castano Group to represent the city on a contingent fee basis: the attorneys would get 20 percent of the recovery if the case settled and 30 percent if it went to trial verdict").

31. See generally Hanoch Dagan \& James White, Governments, Citizens, and Injurious Industries, 75 N.Y.U. L. REV. 354 (2000) (describing the rise of such law suits). It is important to recognize that this may not always be the case. In People ex rel. Clancy $v$. Superior Court, for example, the City of Corona, California, hired a private attorney to bring a nuisance abatement action against a small adult bookstore, agreeing to double the attorney's $\$ 30$ hourly rate if the action was successful. 705 P.2d 347, 348, 350 (Cal. 1985). In County of Santa Clara, the California Supreme Court relied in part on the Clancy defendant's relatively small size to distinguish the holding in that case prohibiting the City of Corona from retaining a private lawyer on a contingent fee from its decision to allow Santa Clara and other counties and municipalities to use contingent fees in compensating private lawyers working as special attorneys general in prosecuting large companies responsible for manufacturing and distributing lead paint. 235 P.3d at 34 (noting that "[d]efendants are large corporations with access to abundant monetary and legal resources"). I return to this distinction below.

32. Plaintiffs' Brief in Opposition To Defendants' Motion To Disqualify the Attorney General's “Unlawfully Retained Contingent Fee" Counsel, Kelley ex rel. Michigan v. Philip Morris Inc., No. 96-842181-CZ (Mich. Cir. Ct. Ingham Cnty. 1996) [hereinafter Kelley Brief], available at http://stic.neu.edu/mi/MTDCOU 1.htm. In a masterful bit of strategy designed to drive this point home, Kelley opened his brief by quoting a lawyer for RJR Reynolds as crowing that "“the way we won these cases was not by spending all of [RJR\}'s[sic] 
Kelley "deemed it to be in the State's best interest to assign three Assistant Attorneys General to the case and then to retain Special Assistant Attorneys General with experience in tobacco litigation to assist in the prosecution of the lawsuit." 33

The word "experienced" is important here. Governments clearly have their own lawyers - and as Frank Kelley himself amply demonstrates, often very good ones. Indeed, as the above quote indicates, Kelley had three full time assistants working on the Tobacco case. I will return to the role of these government lawyers below. But as the Microsoft case demonstrates, even in circumstances where the government unquestionably has significant resources, public lawyers may still believe that they need the assistance of private lawyers with unique skills or experience in order to take on companies that will inevitably marshal the best legal talent money can buy in their own defense. ${ }^{34}$

Moreover, financial considerations have also pushed states to favor hiring these experienced lawyers on some form of a contingent fee. To be sure, some states and localities have decided to follow the Justice Department's lead in the Microsoft case and hire outside lawyers on a reduced hourly fee, or to enlist private lawyers to assist their case pro bono. ${ }^{35}$ Most, however, have opted in favor of arrangements where the outside lawyers will only be paid if the litigation is successful, and where the size of their fee (whether as a matter of contract or judicial determination - a distinction to which I will return below), will depend largely on the amount recovered in the litigation. Such arrangements obviously relieve states from the financial burden of paying the hourly rates of top lawyers - rates that have escalated significantly even since the Microsoft action. ${ }^{36}$ But even if a state or

money, but by making that other son of a bitch spend all of his." Id. (quoting Haines v. Ligget Group, Inc., 814 F. Supp. 414, 421 (D. N.J. 1993).

33. Id.

34. See Robert A. Levy, The Great Tobacco Robbery: Hired Guns Corral Contingent Fee Bonanza, LEGAL Times, Feb. 1, 1999, at 27 (arguing that hiring private lawyers "might be justified to acquire unique outside competence or experience"); see also Erichson, supra note 27 , at 135-37 (describing the expertise of the lawyers who brought the tobacco and gun cases).

35. See Erichson, supra note 27, at 138 (describing Chicago's decision not to bring in plaintiff contingent fee lawyers but to instead rely on a combination of city attorneys, a law professor compensated by the hour, and two law firms working on a pro bono basis). I return to this case and Professor Erichson's analysis below.

36. As noted above, Boies reduced his $\$ 600$ per hour billing rate to $\$ 250$ when working for the federal government. See Bumiller, supra note 25. Today, many mid-level associates bill out at rates higher than $\$ 250$ an hour, while partners of Boies's stature routinely charge more than $\$ 1000$ an hour. See, e.g., Jenna Greene, NY Billing Rates the Highest, but Guess Who Comes in Second?, Legal Times, Sept. 13, 2010, available at http://www.law.com/jsp/nlj/PubArticleNLJ.jsp?id=1202471972166 (citing "[a] massive study of billing rates" revealing that associates in Washington, D.C., for example, charge about "\$375 an hour on average," representing "a relative bargain" compared to other mar- 
municipality were able to find lawyers with the requisite expertise and experience who were willing to work for an hourly rate that the government was willing or able to pay, officials would still have to fund the significant upfront costs and expenses that often are required to mount cases of this kind out of public coffers. ${ }^{37}$ Contingent fee contracts typically shift some or all of these expenses to the outside lawyers. ${ }^{38}$ In an age of dwindling state budgets, it is likely, as one commentator observed, that there will be "industries that will not be taken on, there are cases that will not be brought, unless we allow contingency fees." ${ }^{39}$

But money alone does not tell the entire story. Public lawyers also have political incentives for bringing in high profile private lawyers to assist them in high profile cases. At the state and municipal levels, top public lawyers almost always stand for election. Moreover, these offices often serve as a stepping-stone to higher office at the city, state, or federal level. ${ }^{40}$ Not surprisingly, in seeking to woo voters these lawyer/candidates are quick to tout their experience in helping to shape public policy by curbing corporate abuses through litigation against defendants like tobacco companies and mortgage lenders. ${ }^{41}$ Needless to say, this strategy is unlikely to be particularly successful - at least in the long run - unless the case itself is successfully concluded. To the extent that engaging the services of heavy weight private attorneys increases the odds that the government will be victorious, this political incentive is likely to lead to more such lawyers being hired.

Paradoxically, the political risks associated with losing one of these high-profile cases also increases the incentive to bring in special attorneys general. As much as public lawyers seeking higher office like being seen as champions for the people when they bring these kinds of cases, they ration-

kets such as New York City); Amy Miller, Survey Shows Law Firms Charging Different Rates for the Same Work, CORP. Couns., May 26, 2010, available at http://www.law $. c o m / j$ sp/article.jsp?id=1202458774347 (reporting that "[i]n 2009, partners at law firms charged up to $\$ 1,590$ per hour for work with major corporate clients").

37. See Erichson, supra note 27, at 135 (describing the large, up-front expenses required to mount this kind of litigation).

38. See Erichson, supra note 20, at 38 n.185 (quoting Mississippi’s Attorney General as telling the Tobacco litigation lawyers that "you are going to have to pay all the expenses and it may be as much as $\$ 10$ or $\$ 12$ million").

39. Barbra S. Gillers, Remarks at the Fordham University Law Review Panel Discussion: The Tobacco Litigation and Attorneys' Fees, 67 FordHAM L. REV. 2827, 2840-41 (1999).

40. See John Gramlich, On Campaign Trail, Attorneys General Walk a Fine Line, STATELINE, July 21, 2010, http://www.stateline.org/live/details/story?contentId=499873 (describing Michigan's former Attorney General Mike Cox's run for governor and noting that in 2010 there were "nine other attorneys general who are running for higher office this year (seven for governor and two for U.S. Senate").

41. See id. (describing how attorneys general running for higher office have used litigation against tobacco, social networking and mortgage companies to garner publicity and burnish their credentials). 
ally fear the consequences of losing them even more, since doing so calls into question both their decision to bring the case and their competence in prosecuting the litigation. Bringing in high powered outside talent provides a partial hedge against this latter risk. If the case is successful, the Attorney General can proudly take credit for the victory. But if the case is unsuccessful, the same public official can implicitly blame the setback on the outside lawyer's failure to present a persuasive case-a failure that the Attorney General could not reasonably have anticipated in light of the private lawyer's stellar reputation in litigating actions of this kind. As Jack Coffee argues, political considerations such as these also help to explain why state lawyers favor contingent fees and other similar arrangements since paying the lawyers only if the case is successful frees the Attorney General from the risk of having to later publicly explain to the legislature why significant state funds were "wasted" on a losing effort. ${ }^{42}$ But the fact that the general counsels of large private companies frequently rely on a similar strategy of bringing in high profile — and frequently high priced — outside legal talent as a means of protecting themselves against the downside risks of losing a big case ("But I hired Cravath!") underscores that the politics of CYA (or more politely hedging one's bet) are not confined to the contingent fee context. ${ }^{43}$

Collectively, these monetary and political incentives make it likely that cash-strapped states and municipalities will turn to hiring "substitute" attorneys general with increasing frequency. These same incentives also underscore why this practice has become increasingly controversial.

\section{Should PRIVAte Contingent FeE LAWYERS EXERCISE PUBliC POWER?}

Critics raise several objections to state officials hiring "substitute" private attorneys general, particularly if these lawyers are paid on the basis of some form of contingent fee. As an initial matter, some critics argue this practice exceeds the Attorney General's statutory authority to appoint special attorneys general, or is otherwise prohibited by particular provisions of the state's constitution. These arguments turn primarily on the specific language of the statutes and state constitutional provisions in question and therefore have relatively little impact on the broader questions I am discuss-

42. Coffee, supra note 20, at 251. Of course, if a case is either settled or abandoned prior to a complaint being filed there is likely to be far less publicity. To the extent that actions of this kind are typically disposed of in this manner, the incentives created by either favorable or unfavorable publicity discussed in the text will therefore be diminished. I return to the question of settlement below.

43. See David B. Wilkins, Partners Without Power? A Perliminary Look at Black Partners in Corporate Law Firms, 2 J. Inst. Study LegAl Ethics 15, $32-33$ (1999) (citing this practice as a reason why it is difficult for minority partners to get business, particularly in high profile cases). 
ing here. Moreover, enough state courts have ruled against such claims, ${ }^{44}-$ and enough state legislatures have specifically authorized hiring special attorneys general on a contingent fee basis ${ }^{45}$ (provided that these lawyers work under the supervision and control of public officials $)^{46}$ - that the underlying question of whether to allow private lawyers to exercise state power in this manner is unlikely to be resolved on the basis of a narrow reading of the Attorney General's statutory or constitutional authority in this area.

Nor is it likely that the matter will be resolved on the basis of the general fear that hiring lawyers in this fashion is an invitation to corruption. As the conviction of Dickey Scruggs described above underscores, there is sadly evidence that some public officials and the special attorneys general that they have retained have had the kind of "special" relationship where the latter has "paid to play" this particular role. ${ }^{47}$ Needless to say, these are serious charges. But as others have indicated, they are not unique to this context. The phrase "pay-to-play" comes from the widespread practice in the 1980s of law firms and investment banks lavishly supporting politicians who were in a position to give these firms a piece of the lucrative municipal bond business. ${ }^{48}$ With few exceptions, the banks and law firms that engaged in this practice had much more in common with the law firms that represent the parties who are objecting to hiring substitute attorneys general in these cases than the plaintiffs' lawyers who have typically been hired for this

44. See, e.g., Cnty. of Santa Clara v. Superior Court, 235 P.3d 21, 41 (Cal. 2010); Rhode Island v. Lead Indus. Ass'n, 951 A.2d 428, 480 (R.I. 2008).

45. See, e.g., VA. Code Ann. § 2.2-510.1 (2005); Tex. Gov't Code Ann. § 2254.103 (West 2008); Colo. Rev. StAT. \$§ 13-17-301 to 13-17-304 (2006); see also Mark A. Behrens \& Andrew W. Crouse, The Evolving Civil Justice Reform Movement: Procedural Reforms Have Gained Steam, But Critics Still Focus on Arguments of the Past, 31 U. DAYTON L. REV. 173, 182-83 (2006) (discussing state authorization and regulation of an Attorney General's ability to enter into contingent fee agreements). By contrast, federal agencies are generally barred from using contingent fee lawyers under an Executive Order signed by President Bush. See Exec. Order No. 13433, 72 Fed. Reg. 28441 (May 16, 2007).

46. I will return to the question of exactly how much supervision and control public officials are required to exercise - and the credibility of their claim to do so-below.

47. For example, former Texas Attorney General Dan Morales was sentenced to four years in prison for attempting to steer over $\$ 1$ million in legal fees to himself and another lawyer from the state's $\$ 17$ billion tobacco settlement. See Steve Barnes, National Briefing, Southwest-Texas: Prison for Ex-Official, N.Y. TiMES, Nov. 1, 2003, at A12, available at http://www.nytimes.com/2003/11/01/us/national-briefing-southwest-texas-prison-for-exofficial.html?ref=dan_morales. Similar charges have been leveled at others. See generally Lester Brickman, Remarks at the Fordham University Law Review Panel Discussion: The Tobacco Litigation and Attorneys' Fees, 67 FordHAM L. REV. 2827, 2849 (1999) (arguing that "[i]n most states, the hiring was done on a pay-to-play basis" and that many lawyers were "selected on the basis of the campaign contributions that they made to the state attorneys general").

48. See Jon B. Jordan, The Regulation of "Pay-to-Play" and the Influence of Political Contributions in the Municipal Securities Industry, 1999 Colum. Bus. L. REv. 489, 494 (1999). 
role. ${ }^{49}$ This is not to say, of course, that the possibility of such sweetheart deals should be ignored in this context just because it is present in others. Instead, my point is that the best ways to address "pay-to-play" in hiring substitute attorneys general are likely to be similar to those used in other contexts - a general point to which I shall return below. As a result, the existence of this danger does not provide a special reason for prohibiting the hiring of substitute counsel..$^{50}$

A similar argument applies to critics who object to hiring substitute attorneys general on a contingent fee basis for reasons that are equally applicable to the use of contingent fees in general. Not surprisingly, some of the most vociferous critics of the Tobacco Litigation and other similar cases are the same people who have been railing against the contingent fee in particular, and the litigation system in general, for years. ${ }^{51}$ Although it is possible that these critics will one day win their battle against contingent fees, these arguments have little relevance for the specific question of whether public policy should allow their use in this particular setting.

Recognizing that neither statutory interpretation nor allegations of corruption are likely to carry the day, those who object to the growth in substitute attorneys general raise two other interrelated reasons for condemning this trend. First, even critics who generally support the use of contingent fees in the context of private litigation nevertheless assert that lawyers who are paid on this basis will have an inherent and impermissible conflict of interest when they act as substitute attorneys general. Contingent fee lawyers, according to this argument, seek only to maximize their fees while those who exercise government power should work to maximize the public interest. $^{52}$ For these critics, the analogy is to a public prosecutor whose compensation depends upon obtaining convictions. ${ }^{53}$ Second, many of these same critics assert that contingent fee and other related contracts in this setting undermine fundamental democratic values, either by reducing the legis-

49. See David B. Wilkins, "If You Can't Join 'Em, Beat 'Em!' The Rise and Fall of the Black Corporate Law Firm, 60 STAN. L. REV. 1733, 1770-72 (2008) (arguing that larger firms tended to benefit the most from "pay-to-play" in the municipal bond area).

50. See Erichson, supra note 20, at 35 (reaching a similar conclusion).

51. See, e.g., Walter K. Olson, The Rule of Lawyers: How the New Litigation Elite ThreAtens AmericA's Rule of LAw 102-03, 107-08 (2003); Brickman, supra note 47, at 2830-33. Brickman has been one of the most ardent critics of the use of contingent fees. See, e.g., Lester Brickman, A Rejoinder to the Rejoinder to On the Theory Class's Theories of Asbestos Litigation, 32 PEPP. L. REV. 781, 788 (2005). Similarly, as the title of his book implies, Olson is one of the leading critics of the "evils" of the litigation system.

52. See Erichson, supra note 20, at 36-38.

53. See, e.g., Martin H. Redish, Private Contingent Fee Lawyers and Public Power: Constitutional and Political Implications 4-5 (Apr. 7-8, 2008) (written for the Searle Center's 2008 Research Roundtable on Expansion of Liability Under Public Nuisance (on file with author)) (citing this analogy and arguing that "[i]t is difficult to imagine an arrangement more rife with danger, cynicism and potential abuse than this one"). 
latures' ability to check prosecutorial discretion or by violating the zone of freedom from state action to which individual defendants are entitled under our democratic form of government. ${ }^{54}$

Once again, both of these arguments have merit. As Professor Steven Berenson has observed, "[i]t is an uncontroversial proposition in mainstream American legal thought that government lawyers have greater responsibilities to pursue the common good or the public interest than their counterparts in private practice, who represent non-governmental persons and entities." ${ }^{55}$ As I will argue in the next part, a set of connected changes in both the public and private spheres, of which the practice of hiring substitute attorneys general on contingent fees is just one example, have made the meaning of Professor Berenson's "uncontroversial" assumption significantly more problematic and complex for both government lawyers and private practitioners in many situations. Nevertheless, it is hard to imagine a plausible regime in which public lawyers are not charged with special responsibility for making decisions in the public interest that go beyond those of private lawyers. Moreover, this is particularly true of public prosecutors, who are granted the authority and the duty to bring the full force of the state against those who transgress its laws. In such circumstances, it does indeed seem appropriately "uncontroversial" - and indeed essential - that the prosecutor's goal "in a criminal prosecution is not that it shall win a case, but that justice shall be done." ${ }^{56}$ A system that paid prosecutors on the basis of the number of convictions they obtain would clearly undermine this objective.

The question remains, however, whether this uncontroversial - and incontrovertible-fact is sufficient to rule all contingent fee contracts for substitute attorneys general out of bounds. Although, as I said at the outset, I do not intend to adjudicate this claim definitively here, there are several reasons to suspect that the analogy to criminal prosecutors is not as persuasive as some critics have suggested - and that the distance between what is actually going on in most of these cases and practices that these same critics deem acceptable and even desirable is far less than they appear to believe. With respect to the former, it has long been recognized that the criminal context confers special duties on prosecutors-and special rights on defendants - that distinguish it from other kinds of litigation, even where the government is a party. Prosecutors in criminal cases have a constitutional

54. See Erichson, supra note 20, at 38-40 (articulating the first objection that contingent fees remove appropriate legislative checks on prosecutors); Redish, supra note 53, at 32-33 (articulating the second objection relating to the Due Process rights of defendants) (see also the sources cited therein).

55. Steven K. Berenson, Public Lawyers, Private Values: Can, Should, and Will Government Lawyers Serve the Public Interest?, 41 B.C. L. REV. 789, 789 (2000).

56. See Berger v. United States, 295 U.S. 78, 88 (1935). 
[Vol. 2010:423

duty to turn over potentially exculpatory evidence, ${ }^{57}$ ensure that defendants are made aware of their right against self-incrimination, ${ }^{58}$ and refrain from using evidence that was collected in violation of the defendant's right to unreasonable searches and seizures under the Fourth Amendment. ${ }^{59}$ To ensure the prosecutor's compliance with these mandates, defendants are in turn guaranteed the right to an attorney ${ }^{60}$ who must represent their interests "effectively" for a conviction to be upheld. ${ }^{61}$ None of these duties or rights applies in civil litigation. To be sure, these differences do not mean that outside of the criminal context, prosecutors have no obligation to "seek justice" instead of mere victory. ${ }^{62}$ It is just to note that this obligation is not the same as the duties that prosecutors have in criminal cases.

The California Supreme Court's recent decision in County of Santa Clara v. Superior Court underscores this distinction. ${ }^{63}$ In Santa Clara, a group of businesses being sued in a public nuisance action by a number of California counties and cities for manufacturing and distributing lead paint sought to bar the public entities from compensating their privately retained counsel by means of contingent fees. ${ }^{64}$ In making this claim, the defendants relied on People ex rel. Clancy v. Superior Court ${ }^{65}$ in which the same court in 1985 invoked the strict neutrality principle applicable to criminal prosecutions to bar a municipality from paying a private lawyer a partial contingent fee to prosecute a public nuisance action against the owner of a small adult bookstore. ${ }^{66}$ In Santa Clara, however, the court made clear that not every civil case in which the government is a litigant "invoke[s] the same constitutional and institutional interests present in a criminal case." ${ }^{97}$ Thus, when the government is acting as an "ordinary" litigant enforcing its own contract and property rights," the court observed, "we do not require neutrality." Although the public nuisance actions at issue in Santa Clara are

57. Brady v. Maryland, 373 U.S. 83, 87 (1963).

58. Miranda v. Arizona, 384 U.S. 436, 444 (1966).

59. Mapp v. Ohio, 367 U.S. 643, 655 (1961).

60. Gideon v. Wainright, 372 U.S. 335, 342 (1963).

61. Strickland v. Washington, 466 U.S. 668, 669 (1984).

62. Bruce A. Green, Must Government Lawyers "Seek Justice” in Civil Litigation?, 9 Widener J. Pub. L. 235, 256 (2000) (arguing that "[j]udicial decisions and other professional writings take the view that, even outside the context of criminal prosecutions, government litigators have a different role and different ethical responsibilities from lawyers representing private litigants").

63. 235 P.3d 21, 35-36 (Cal. 2010).

64. Id. at 25 .

65. 705 P.2d 347 (Cal. 1985)

66. Cnty. of Santa Clara, 235 P.3d at 29 (citing Clancy as holding that "the neutrality rules applicable to criminal prosecutors were equally applicable to government attorneys prosecuting certain civil cases").

67. Id. at 31 .

68. Id. at 33 . 
not simply private, the court acknowledged, neither do they invoke the same kind of liberty interests at stake in the typical criminal case, or even the threat of shutting down an ongoing business at issue in Clancy. Instead, "at most" defendants will have to "expend resources to abate the lead-paint nuisance they allegedly created," which, the court underscored, is the "type of remedy one might find in an ordinary civil case." ${ }^{69}$ As a result, the court concluded, actions of this kind do not "affect the type of fundamental rights implicated in criminal prosecutions or in Clancy," and therefore, "the absolute prohibition on contingent-fee arrangements imported in Clancy from the context of criminal proceedings is unwarranted." ${ }^{70}$

Moreover, in deciding the conditions under which contingent fees should be allowed in public nuisance actions of this kind, the Santa Clara court highlighted several other features of this type of litigation that are plausibly relevant to a fair determination of whether hiring substitute attorneys general on this basis threatens important systemic values. In most criminal prosecutions, the court observed, there was a "profound imbalance between the institutional power and resources of the government and the limited means and influence of the defendants - whose vital property rights were threatened." ${ }^{\prime 71}$ As the court correctly notes, however, in the case before it - and in virtually all of the recent cases where governments have sought to bring in substitute attorneys general-there is no such imbalance. Instead, these defendants tend to be "large corporations with access to abundant monetary and legal resources." 72 A quick perusal of the who's who of lawyers representing the defendants in Santa Clara makes abundantly clear that these powerful actors are making full use of the opportunity that their size and resources afford them to mount a vigorous defense. ${ }^{73}$ As a result, the risk that the government will abuse its authority by either overreaching or applying economic coercion, as the Santa Clara court correctly concluded, is significantly reduced..$^{74}$

69. Id. at 34 .

70. Id. at 34-35; see also Rubenstein, supra note 18, at 2146 (arguing that " $[\mathrm{t}] \mathrm{he}$ substitute attorney general is a first step on the spectrum away from the purely public side; she is removed not only because she is a private attorney substituting for a public one, but also because she tends to perform more private-like functions than those that constitute the core of the attorney general's work").

71. Santa Clara, 235 P.3d at 32.

72. Id. at 34.

73. See id. at 24-25 (listing such prominent law firms as Arnold \& Porter; Orrick, Herrington \& Sutcliffe; McGuire Woods; Jones Day; Shook, Hardy \& Bacon; Latham \& Watkins; and Akin Gump Strauss Hauer \& Feld as appearing on behalf of the defendants).

74. To say that the defendants' size and resources "reduces" the risk of government overreaching should not be read to imply that there is no danger of attorneys general abusing their power when pursuing powerful private corporations. One need only look at the Department of Justice's ability to force companies to "voluntarily" waive their attorney-client privilege as a pre-condition to even obtaining a hearing with government officials to under- 
Finally, the Santa Clara court stressed that the situation before it differed fundamentally from one where a criminal prosecutor-or any other decision-maker with ultimate authority - was being paid on the basis of the outcome of the case because "neutral, conflict-free government attorneys retain the power to control and supervise the litigation." 75 This control and supervision, the court emphasized, must go beyond "boilerplate language" to "specifically provide that decisions regarding settlement of the case are reserved exclusively to the discretion of the public entity's own attorneys" and "that any defendant that is the subject of such litigation may contact the lead government attorneys directly, without having to confer with contingent-fee counsel." ${ }^{\prime 76}$ Citing the Rhode Island Supreme Court's recent approval of contingent fees in a similar public nuisance case against the manufacturers of lead paint, the Santa Clara court went on to endorse three guidelines for determining whether agreements between public attorneys general and the private lawyers they bring in on a contingent fee basis to assist them pass muster:

stand that the state has potent weapons capable of bringing even the most powerful private corporation to its knees. See Gretchen Elizabeth Eoff, Losing the War on Attorney-Client Privilege: Viewing the Selective Waiver Quagmire Through the Tenth Circuit's In re Qwest Communications International, DEF. Couns. J., Jan. 1, 2008, available at http://www.allbusiness.com/legal/evidence-privileged-communications/8891799-1.html (noting the "harsh reality" in which "companies accused of wrongdoing, or who engage in voluntary . . . self-reporting, are often forced to selectively waive attorney-client privilege in order to be judged as 'cooperating' with federal prosecutors of government agencies under current governmental policies."). As Howard Erichson points out, governments have other weapons - including subpoena power, the ability to circumvent joinder issues and other collective action problems, and the threat of issue preclusion in subsequent private litigation - that give public litigants a significant advantage when taking on powerful corporation like the tobacco companies. Erichson, supra note 20, at 28-30. As I argue below, these advantages - and their concomitant potential for abuse - are relevant to defining what the public responsibilities of government lawyers toward the private parties over whom they inevitably hold power should be. In defining these responsibilities, however, it is also important to account for the ability that corporate clients have to press public officials to curb their abusive practices - a strategy that has resulted in a significant modification (albeit certainly less than what many companies and their lawyers would have wanted to see) of the Justice Department's policy concerning the circumstances where it is appropriate to ask companies to waive their attorney-client privilege. See, e.g., David Z. Seide, Is the Department of Justice's McNulty Memorandum a Cure-All?, 15 CORP. GovernANCE AdvisOR, Mar.-Apr. 2007, at $1, \quad 1-4$, available at http://lawprofessors.typepad.com/whitecollarcrime_blog /files/seide_article_is_the_dojs_mcnulty_memo_a_cureall.pdf (describing the efforts that lead up to the revision of the Justice Department's original waiver policy and adoption of the McNulty Memo); see also Attorney-Client Privilege Bill Introduced in the House, MAIN JuST. (Dec. 17, 2009, 9:59 PM), http://www.mainjustice.com/2009/12/17/attorney-clientprivilege-bill-introduced-in-the-house/ (reporting on efforts to introduce a bill to prohibit the Justice Department from requesting a waiver of the attorney-client privilege as a measure of cooperation in civil and criminal investigations).

75. Santa Clara, 235 P.3d at 36.

76. Id. at 39-40. 
Contingent-fee agreements between public entities and private counsel must provide: (1) that the public-entity attorneys will retain complete control over the course and conduct of the case; (2) that government attorneys retain a veto power over any decisions made by outside counsel; and (3) that a government attorney with supervisory authority must be personally involved in overseeing the litigation. $^{77}$

Then and only then, the court concluded, is it permissible for government officials to bring in substitute attorneys general on this basis.

Not surprisingly, those who oppose this practice have questioned whether this kind of supervision can ever really be effective in practice. Lawyers with day-to-day responsibility for litigating cases, these critics argue, inevitably exercise significant discretion over which strategies to pursue and how to pursue them. Given their strong financial interest in maximizing the size of the monetary recovery from which their fees will be paid (whether directly or indirectly), contingent fee lawyers will invariably steer the litigation in ways that place their own financial interests over those of their putative public supervisors and the public interest these officials are supposed to represent. ${ }^{78}$ Moreover, the failure of state officials to check this natural tendency will be virtually impossible for either defendants or courts to see since most of the conversations upon which any such assessment would be based will be held in private, and will arguably be shielded by either the work product or the attorney-client privilege. ${ }^{79}$ The fact that government lawyers have been promising to constrain this "investment mentality" since the days that Frank Kelley and his fellow AGs first pioneered this form of litigation in the Tobacco cases ${ }^{80}$ is hardly likely to give those who are skeptical about the effectiveness of public oversight much comfort.

Once again, these are far from frivolous concerns. As Professor Erichson has documented, for example, one can see the potential impact of the incentives that private contingent fee lawyers bring to these kinds of

77. Id. at 40 .

78. See Redish, supra note 53, at 18-19 (making this claim).

79. See Press Release, John H. Sullivan, President of the Civil Justice Ass'n of Cal., Statement on County of Santa Clara v. Superior Court, (July 26, 2010), available at http://www.cjac.org/newsandresearch/press-releases/county-of-santa-clara-v-superi/ (criticizing the Supreme Court's test in Santa Clara by asking "[h]ow is any objective observer to know whether 'oversight' requirements such as 'public entity lawyer control . . . veto power' either exist in a contingency fee agreement or are being met in practice?"). As a "reality check" Sullivan goes on to contend that "[1]ast March 12 District Attorney Tony Rackauckas announced a 'contingency fee' agreement with an Orange Country-based law firm to sue Toyota" which "[d] espite media and private citizen requests . . . has not been made public" on the basis of an opinion by a county attorney "that it is privileged as attorney-client communication." Id.

80. See Kelley Brief, supra note 32 (arguing that the Memorandum Agreement between the Attorney General's office and private contingent fee lawyers including Dickie Scrugg specifically provides that "the Attorney General retains control over all aspects of the litigation"). 
cases by examining the differing litigation strategies in two actions that were filed against gun manufacturers within two weeks of each other: one by the City of New Orleans, which chose to retain the same plaintiffs' lawyers who litigated the Tobacco cases as substitute attorneys general, and the second filed by the City of Chicago, which relied on a combination of public lawyers and private attorneys working either on an hourly basis or pro bono to pursue their claims. ${ }^{81}$ In the former case, New Orleans pursued a strategy of characterizing firearms as "defective products" that was similar in many ways to the theories these same lawyers had successfully put forward in the Tobacco cases. In Chicago, on the other hand, the City pressed a theory that emphasized the threat that guns posed to public safety, particularly in inner city neighborhoods. As Erichson argues, the "tort law" approach taken by New Orleans was far more likely to lead to a big damage award than the "law enforcement" theory pursued by the lawyers in Chicago, which more naturally fit with obtaining injunctive or other forms of equitable relief. ${ }^{82}$ This "investment mentality" on the part of private tort lawyers in which they are motivated primarily by their desire to recoup the money and time that they have sunk into the case, Erichson concludes, will produce decisions that "do not always correspond to the decisions that government officials would make as a matter of policy or politics." 83 The fact that many of the gun cases where traditional mass-tort plaintiffs' lawyers were brought in to act as substitute attorneys general were quickly dropped when these lawyers realized that they would be far more difficult and costly to litigate than they first anticipated provides support for this conclusion. ${ }^{84}$

Nevertheless, these concerns seem overblown - or at the very least, subject to workable amelioration, albeit not a complete solution. Although defendants cannot be privy to every conversation between public and private lawyers to ensure that the latter are appropriately supervised by the former, courts can and should require that the documents that grant private attorneys the right to act as substitute counsel be made available to opposing parties - and to the public at large. Such "Sunshine Act" procedures, particularly when accompanied by competitive bidding or other similarly open selection processes, will go a long way toward ensuring that public entities

81. See Erichson, supra note 27, at 134-38 (describing both cases).

82. Id. at 147 (arguing that "[p]rivate lawyers naturally bring a mass tort/product liability orientation, whereas public lawyers are more likely to bring a law enforcement orientation"). The risk of this kind of divergence is likely to be particularly acute in cases like the Gun Litigation which have a clearly defined "law enforcement" component. This component is likely to be less present in many consumer cases where the state's primary interest is in compensation.

83. Id.

84. See id. at 140 (describing lawsuits in Boston and Cincinnati brought by traditional mass tort lawyers that were voluntarily dismissed after it became clear that they would be both protracted and expensive). 
have at least formally instituted the kind of procedures set out by the court in Santa Clara, as well as providing an important bulwark against the payto-play corruption that has sometimes infected the decision to hire counsel in the first instance. ${ }^{85}$ As the Santa Clara court acknowledged, at present these safeguards have not been implemented in many cases. ${ }^{86}$ But the momentum is moving in this direction, fueled by decisions like Santa Clara and scandals like the one involving Dickey Scruggs.

Consider, for example, the contract between the state of Nevada and the law firm of Cohen, Milstein, Sellers \& Toll authorizing the latter to act as special attorneys general in a law suit filed by the state against several mortgage lenders for engaging in various forms of deceptive and fraudulent lending practices that caused substantial harm to Nevada residents. ${ }^{87}$ The document, which was entered into before the court's decision in Santa Cla$r a$, expressly covers every area the court identified in that case and a great deal more. Thus, with respect to decision-making authority over the prosecution of the litigation, the contract provides that "[i]t is expressly understood that the Attorney General will have final and exclusive authority over all aspects of this case, including settlement decisions" and that she may "settle all or part of the related Litigation over the objection" of Cohen Milstein. ${ }^{88}$ Moreover, the law firm is required to discuss with the Attorney General "all major litigation decisions" such as which defendants to name and what claims to pursue, and to obtain her "written approval" before "taking any positions that could potentially impact policy concerns of the State" and to provide her "with drafts of any court filings sufficiently in advance of filing the documents in order for the Attorney General to review the filings

85. Richard L. Cupp, Jr., State Medical Reimbursement Lawsuits After Tobacco: Is the Domino Effect for Lead Paint Manufacturers and Others Fair Game?, 27 PEPP. L. REV. 685, 699 (2000) (advocating in favor of this kind of approach).

86. 235 P.3d 21, 40-41 (Cal. 2010) (acknowledging that only five of the ten fee agreements at issue contained an express acknowledgement that public officials retained "final authority over all aspects of the litigation" and that none of the contracts contained sufficient detail to meet the court's new standard). As a result, the court remanded all ten cases back to the court of appeals to oversee the drafting of contracts consistent with the court's opinion. Id. at 40 .

87. Exhibit A to First Amended Complaint for Declaratory and Injunctive Relief, Contingency Fee Professional Services Agreement, Lennar Corp. v. Cortez-Masto, No. 1:10cv-00378-HHK, (D.D.C. Aug. 11, 2010) [hereinafter Fee Agreement] (pleading on file with the author). I am grateful to Joseph Sellers, Betsy Miller, and Linda Singer of Cohen Millstein for bringing this case to my attention and sharing these public documents with me.

88. Id. $\S 1.1$. There is one exception to the Attorney General's plenary authority in this area that bears mentioning. In the event of a settlement "for injunctive relief only" the contract provides that Cohen and Milstein will receive "costs and hourly fees at fair market value of their legal services expended on behalf of the state." Id. § 3.5.4. "In such an event," the contract continues, "the State agrees not to settle the case unless the defendant agrees to pay said amount." Id. I return to the significance of this exception in Part IV. 
and provide comments, unless the Attorney General affirmatively waives such review." "89

To be sure, no contract provision is self executing-let alone selfenforcing. But the fact that both the Attorney General and Cohen Milstein have publicly and explicitly specified their respective rights and duties provides the well-funded defendants in this case a record on which to hold these parties accountable for whether they are living up to their commitments. Although the attorney-client and work product privileges may shield the substance of the conversations that the Attorney General has with her substitute counsel, it should not block inquiry into whether the procedural terms relating to notice and decision making authority specified in the agreement are being honored. Indeed, the contract specifically states that government attorneys "will be actively involved in all stages of this matter and deciding all major issues, including whether to file suit, when to file suit, who to file suit against, approval of the asserted claim or claims and whether and on what basis to settle or proceed to trial." 90 Moreover, as the Santa Clara court made clear, defendants must be afforded direct access to government lawyers, providing a potent weapon to ensure that public lawyers are actually in control of the case. ${ }^{91}$ The fact that defendants in this case have filed a motion to disqualify Cohen Milstein in the District Court for the District of Columbia indicates that they are certainly capable of trying to protect their rights in this manner.

Finally, any award of attorney's fees to Cohen Milstein must be approved by the court. ${ }^{92}$ Although this provision does not make the firm's fee agreement with the state any less "contingent," ${ }^{93}$ it does provide an additional level of review for a defendant who believes that the firm-or the Attorney General's office - has abused its respective authority. Needless to say, court supervision of fee awards in other contexts suggests that simply requiring judicial approval is no guarantee against abuse. Nevertheless, defendants are given ample opportunities to raise any objections-and

89. Id. $\S \S 1.1-.2$.

90. Id. $\$ 8.1 ;$ see also $\$ \S 1.1,9$.

91. 235 P.2d at 39-40 ("[R]etention agreements between public entities and private counsel . . . must specify that any defendant that is the subject of such litigation may contact the lead government attorneys directly, without having to confer with contingent-fee counsel.").

92. Fee Agreement, supra note 87, § 3.2 ("The reasonableness of the attorney's fees must be approved by the court.").

93. Under a provision labeled "Contingency" the agreement expressly provides: "Neither the Attorney General nor the State is liable under this Contract to pay compensation to Contractor, other than from monies which may be paid to the State or its agencies party to the Litigation, whether by settlement or judgment, from any entities named as defendants in the Litigation." Id. § 3.1 . 
courts appear to be increasingly scrutinizing fee arrangements, ${ }^{94}$ presumably sensitive to a range of impermissible arrangements and abuse, including "sweetheart" deals for plaintiffs' attorneys.

Indeed, a more open process is likely to affect the kind of lawyers who are hired as substitute attorneys general in the first instance. As critics point out, the potential for conflicts of interest between the "investment mentality" of private lawyers and the public goals that ought to guide litigation on behalf of the state are likely to be most severe when the state engages the kind of mass-tort lawyers who brought the Tobacco cases and who are now searching for new causes of actions in which to invest their war chests. ${ }^{95}$ Even with respect to these lawyers, however, the story turns out to be more complicated than this simple caricature would suggest. As Howard Erichson documents in his excellent study of the litigation against the gun industry, even some of the traditional plaintiffs' lawyers who moved from tobacco to guns were motivated in part by a sincere belief that handguns "were dangerous products, causing widespread harm that imposed costs not only on individuals but also on society as a whole." 96 As a result, Erichson argues, these lawyers expended far more time, energy, and most importantly money on attempting to hold the industry responsible for these harms than would have been warranted by a simple economic calculus of the likely return on their investment. ${ }^{97}$ Moreover, precisely because of the high profile nature of the Gun Litigation, the traditional plaintiffs' lawyers who were deputized by state attorneys general to litigate these cases increasingly found themselves working alongside public interest lawyers whose primary interest was in reducing gun violence rather than in maximizing fees. ${ }^{98}$ These lawyers, Erichson concedes, provided a partial check on the extent to which the investment decisions of the traditional mass tort lawyers shaped the litigation. ${ }^{99}$

94. See, e.g., Hall v. AT\&T Mobility, LLC, No. 07-5325, 2010 WL 4053547, *16 (D.N.J. Oct. 13, 2010) ("[T] he district court should "engage in robust assessments of the fee award reasonableness factors recognizing an especially acute need for close judicial scrutiny of fee arrangements in class action settlements."') (quoting In re AT\&T Corp., 455 F.3d 160, 166 (3rd Cir. 2006) (internal citations omitted)).

95. Redish, supra note 53, at 7-8 (discussing this motivation).

96. Erichson, supra note 27, at 136 (describing the motivations of Wendell Gauthier, the substitute attorney general hired by New Orleans and one of the principal architects of the gun litigation nationally).

97. Id. at 145-46 (arguing that it is difficult to explain the gun litigation in simple "entrepreneurial terms" and that Gauthier continued to fight the case long after it was clear that there was no "pot of gold" at the end even if the case was successful).

98. See id. at 139 .

99. Once again, this is partially a function of the unique nature of the public safety issues presented in the Gun Litigation. The fact that several law professors and public interest organizations filed amicus briefs in support of allowing city and county governments to engage private contingent fee lawyers in the Lead Paint litigation at issue in Santa Clara, 
In recent years, however, states and municipalities appear to be turning to a different kind of law firm to represent their interests in cases against corporate defendants. In Santa Clara and the Nevada mortgage lending cases, for example, traditional mass-tort law firms like Motley Rice and Thornton \& Naumes (both of which were prominent in the Asbestos and Tobacco litigation) are being joined —or replaced—by law firms like Cohen Milstein and Cotchett, Pitre \& McCarthy that expressly hold themselves out as embracing a strong social justice mission. ${ }^{100}$ Although all plaintiffs' law firms claim to "seek justice," for the most part these claims are cast solely in terms of obtaining compensation for victims through personal injury and mass-tort litigation. ${ }^{101}$ Firms such as Cohen Milstein and Cotchett, Pitre \& McCarthy, by contrast, are organized around a broader social justice mission that is reflected in the areas in which they practice, ${ }^{102}$ their significant commitment to pro bono, ${ }^{103}$ and in the backgrounds and commitments of

however, suggests that the close working relationship between these substitute attorneys general and the public interest bar is not unique to the Gun Litigation.

100. This mission is prominently reflected on each firm's website. See, e.g., CoHEN MiLSTEIN, http://www.cmht.com/home.php (last visited Oct. 20, 2010) (titling their site "Access to Justice" and prominently featuring a quote from Corporate Legal Times touting the firm as "[t]he most effective law firm in the United States for lawsuits with a strong social and political component" at the top of their home page); CotCHETT, PITRE \& MCCARTHY, http://www.cpmlegal.com/ (last visited Oct. 20, 2010) (stating in the firm's initial website paragraph that "[ $\mathrm{t}]$ he firm's dedication to prosecuting or defending socially just actions has earned it both a national and statewide reputation").

101. See, e.g., Firm Profile, Motley Rice, http://www.motleyrice.com/info/firmprofile (last visited Oct. 20, 2010) (noting that "Motley Rice seeks justice and accountability on behalf of people and institutions harmed by wrongdoing and negligence" and touting its extensive experience in litigating cases involving occupational disease and workers rights in cases like asbestos and tobacco).

102. Although both Cohen Milstein and Motley Rice claim to specialize in securities and consumer fraud, Cohen Milstein has a strong presence in civil rights and human rights litigation, whereas Motley Rice's expertise lies primarily in traditional tort law areas such as product liability, medical malpractice, and catastrophic disasters such as airplane crashes and environmental lawsuits such as the BP Oil Spill. Compare COHEN MiLSTEN, supra note 100, with MOTLEY Rice, supra note 101.

103. Cohen Milstein's website features a home page link to its Pro Bono activities listing numerous awards for the firm's pro bono work on high profile cases, including seeking compensation from the 9/11 fund and law suits on behalf of Holocaust survivors against Swiss banks. Pro Bono, CoHN MiLSTEIN, http://www.cmht.com/probono.php (last visited Oct. 20, 2010) (leading with a quote from Kenneth Feinberg saying that the firm is "willing to dig into their pockets and do whatever is necessary for their clients"). Motley Rice, on the other hand, has no link for Pro Bono on its site but instead has a link describing its contributions to "local, national, and international non-profit organizations that work to strengthen our communities and enhance the quality of life for others." Community Connections, MotLey Rice, http://www.motleyrice.com/info/community-connections (last visited Jan. 8, 2011). 
their lawyers. ${ }^{104}$

These differences are reflected in the manner in which the two kinds of firms organize their representation of state and local clients. Cohen Milstein has a dedicated "Public Clients" practice group headed by the former Attorney General for the District of Columbia. ${ }^{105}$ Although Motley Rice also has extensive experience in representing public clients as substitute attorneys general, such cases are not listed among the firms special "Case Types" on its home page and instead are handled by lawyers such as Joseph Rice who lists his representation of twenty-six Attorneys General in the Tobacco Litigation as part of his general expertise in handling complex class actions in a range of areas from asbestos to securities fraud. ${ }^{106}$

Needless to say, these differences in structure, orientation, and personnel do not mean that firms like Cohen Milstein will necessarily discharge their role as substitute attorneys general in ways that are better aligned with the public responsibilities of their governmental clients than more traditional firms such as Motley Rice. As Derrick Bell reminded us long ago, ideological motivations can cloud a lawyer's judgment every bit as much as financial interests. ${ }^{107}$ But it does seem likely that firms that are attempting to operate "between profit and principle" 108 will be less likely to

104. For example, three of the four named partners at Cohen Milstein spent significant time in government or public interest organizations before joining the firm. Attorneys, COHEN MilsteIN, http://www.cmht.com/attorneys.php (last visited Oct. 20, 2010) (listing Jerry S. Cohen (Michigan Attorney General's office and Senate Antitrust Committee), Herbert E. Milstein (Securities and Exchange Commission), and Joseph Sellers (Equal Opportunities Commission, Department of Justice Civil Rights Division, and the Washington Lawyers Committee for Civil Rights Under Law)). By contrast, neither Motley nor Rice list any public sector or public interest experience on their web pages.

105. See Linda Singer, COHEN MiLSTEIN, http://www.cmht.com/attorneys.php?People ID=59 (last visited Oct. 20, 2010) (describing Ms. Singer as the head of the Public Client practice group and listing her background and credentials). Ms. Singer is joined in the practice by Betsy Miller who served as Ms. Singer's Chief of Staff and Senior Counsel at the DC Attorney General's office before joining the firm. See Betsy Miller, CoHEN Milstein, http://www.cmht.com/attorneys.php?PeopleID=6; see also Practice Areas-Qui Tam, CROCHETT, PITRIE \& MCCARTHY, http://www.cpmlegal.com/practicearea-quitam.php (last visited Oct. 20, 2010) (describing the firm's practice in bringing lawsuits by "whistleblowers" on behalf of the state to recover money from corporations that have defrauded the government). As William Rubenstein argues, lawyers who bring such actions are also properly characterized as substitute private attorneys general. See Rubenstein, supra note 18, at 214445.

106. Joseph F. Rice, MotLEY RicE, www.motleyrice.com/attorneys/view/joseph-frice (last visited Oct. 20, 2010).

107. See generally Derrick A. Bell, Jr., Serving Two Masters: Integration Ideals and Client Interests in School Desegregation Litigation, 85 YALE L.J. 470 (1976).

108. See Scott Cummings \& Ann Southworth, Between Profit and Principle: The Private Public Interest Firm, in Private LAWYers AND THE Public InTERest: The Evolving Role of Pro Bono in the Legal Profession 186 (Robert Granfield \& Lynn Mather, eds. 2009) (describing "private public interest firms" as "organized as for-profit entities, but 
[Vol. 2010:423

approach these cases solely from the "investment mindset" that the critics of allowing contingent fees in this area fear, particularly when the lawyers who are handling the cases have a deep personal and professional identification with the public clients that they are representing. ${ }^{109}$ Indeed, to the extent that these firms are trying to build sustainable practices in this area, they now have an important reputational interest in making sure that the perceived gap between what public clients want and what these firms are perceived as providing in terms of strategy, direction, and investment does not become so great as to threaten their future retention. As hiring and contracting decisions become more public, both private defendants and ordinary citizens will have a greater ability to ensure that neither the substitute attorneys general nor the government officials who hire them are trading on this reputation for short-term gain.

This latter point suggests why the second group of objections grounded in democratic accountability and individual rights are also less persuasive than they might appear at first blush. There is certainly some truth in Jack Coffee's characterization of an attorney general's decision to hire substitute counsel on a contingent fee basis as a version of "heads, we win and the state recovers its losses; tails we lose, but we incur no out-ofpocket loses and we hired the best people available." 110 Whether this undermines the legislature's authority over spending, however, is far less certain. With respect to legislative control, the publicity surrounding both the initiation and prosecution of these kinds of cases seems likely to give legislatures and public officials plenty of notice and opportunity to express their views. The fact that so many state Attorneys General aspire to higher political office gives these officials strong incentives to ensure that cases of this kind receive maximum publicity. ${ }^{111}$ As even those who worry that hiring contingent fee lawyers may undermine legislative control over spending

advancing the public interest is one of their primary purposes - a core mission rather than a secondary concern"). Needless to say, whether Cohen Milstein or Crochett Pitrie fully merit this designation is beyond the scope of this inquiry - although the differences cited above certainly suggest that these firms are attempting to portray themselves as if they do. My point simply is that state officials can and should look to see whether the law firms that they hire as substitute attorneys general have this orientation - and defendants and the public at large can and should hold public officials accountable for whether they in fact engage in this inquiry.

109. I return to the issue of professional identity below.

110. Coffee, supra note 20, at 251.

111. Indeed, opponents criticize the fact that sitting attorneys general make such frequent use of this bully pulpit because it affords these state officials an unfair advantage on the campaign trail. See Gramlich, supra note 40 (describing how California Attorney General and gubernatorial candidate Jerry Brown "spent much of last week making televised public appearances to tout the work he is doing as the state's top lawyer, including expanding the state's DNA database and suing the nation's two largest mortgage lenders," all without airing a single campaign commercial). 
concede, "[i]n high-profile litigation, political incentives may drive litigation decisions notwithstanding the retention of contingent fee lawyers." 112

Indeed, as Jack Coffee argues, such political considerations are likely to be dominant regardless of whether the Attorney General hires substitute counsel or how they are paid. Whether or not one believes that politicians are solely motivated by some combination of personal gain (whether measured by money or electoral success) and interest group pressure, ${ }^{113}$ no credible theory of politics claims that these considerations do not play a significant role in the decision-making of public officials. As a result, the primary considerations for both Attorneys General and legislatures in deciding whether to bring these cases are likely to be political. Most of the litigation that has been filed by states and municipalities in recent years has targeted industries - tobacco companies, gun manufacturers, lead paint producers, mortgage lenders, HMOs, and most recently $\mathrm{BP}$ - that were already quite unpopular with a significant part of the population at the time the cases were brought. It is not surprising, therefore, that Attorneys General have decided to proceed against these particular defendants, and that several state legislatures have specifically authorized them to do so. ${ }^{114}$ Although one can certainly argue whether cases like this are likely to make good law, bringing such actions appears to be good politics. And where it is not good politics, the case is likely to have a much shorter half-life.

Moreover, while the availability of contingent fees will certainly put a thumb on the scale in favor of suing, this incentive also acts as a counterweight against the strong incentives that politicians face not to sue such powerful private interests. As Marc Galanter taught us more than forty years ago, one of the main reasons that the "have's" tend to come out ahead in litigation is that they have the ability to "play for the rules" by lobbying to create favorable policies or procedures - or just as importantly to block unfavorable ones - in a manner that shifts the litigation terrain dramatically

112. Erichson, supra note 20, at 40. Indeed, in light of the political risks associated with losing such high profile actions, Attorneys General are unlikely to bring these cases in the first place unless they know that they have a very strong case. The fact that state officials are entitled to use their subpoena power to collect important factual information prior to bringing suit will further reinforce their tendency to move forward only on cases where there is a significant probability of success. See generally id. I return to the issue of the government's subpoena power below. Notwithstanding these incentives, however, the Gun Litigation underscores that sometimes public officials will bring actions where there is a relatively low chance of success. See Erichson, supra note 27, at 129-51 (describing the legal and factual difficulties encountered by the lawyers who brought the gun cases).

113. See generally Cass R. Sunstein, Interest Groups in American Public Law, 38 StAN. L. REV. 29 (1985).

114. See infra note 117 and accompanying text regarding states that have passed legislation specifically authorizing contingent fee suits. 
in their favor. ${ }^{115}$ To be sure, the Attorney General is not a typical "oneshot" litigant. But neither does he or she have the same ability to influence legislation through campaign donations and targeted advertising that tend to have the most direct influence on elected representatives. ${ }^{116}$ These weapons are likely to be particularly potent in the context of an Attorney General's attempt to procure a specific funding authorization to bring a lawsuit against a well-funded and politically connected adversary. It might be successful in a case like BP where there is a strong enough public outcry to make it difficult for legislators to vote against it, but in many other cases the advantages held by industry lobbyists will simply be too great to overcome. ${ }^{117}$

Indeed, this is precisely why courts and legislatures have embraced the concept of the "private attorney general" - and more generally "public law litigation"-in the first place. Although as my colleague William Rubenstein has argued, there have been a multitude of definitions of and justifications for these concepts, ${ }^{118}$ one important strain is the recognition that there will inevitably be some important public interests that are too diffuse to gain legislative recognition - particularly when opposed by interests that are both concentrated and well financed - and that public officials can and should harness private incentives to supplement public enforcement. ${ }^{119}$ Thus, the complaint that "[b]y the use of contingent fee layers, Attorneys General gain an unparalleled ability to determine the size of their own agency budgets" 120 ignores the fact that both Attorneys General and legislatures have been using the concept of the private attorney general to expand state enforcement resources for more than fifty years. Although legal doctrines

115. See Mark Galanter, Why the "Haves" Come Out Ahead: Speculations on the Limits of Legal Change, 9 LAW \& Soc'y Rev. 95 (1974). See also In Litigation: Do THE "HAves" Still Come Out AHEAD? (Herbet M. Kritzer \& Susan S. Silbey eds., 2003).

116. See Lynn Mather, Theorizing about Trial Courts: Lawyers, Policymaking, and Tobacco Litigation, 23 LAW \& Soc. INQUIRY 897, 909 (1998) (noting that legal claims against the tobacco industry filed by state governments using private contingent fee lawyers were an important means of "overcom[ing] well-known facts about 'why the 'haves' come out ahead' in litigation") (citing Galanter, supra note 115).

117. Indeed, the fact that at the time of this writing the legislation authorizing the Louisiana Attorney General to hire contingent fee counsel to litigate against BP is still stuck in committee suggests just how difficult it is to get authorization from the legislature even in cases where the defendant is extremely unpopular and the state is not being asked to appropriate funds directly from the public coffer. See Caldwell's Office to Receive Another \$5 Million, supra note 14.

118. Rubenstein, supra note 18.

119. For the classic description of public law litigation, see Abram Chayes, The Role of the Judge in Public Law Litigation, 89 HARV. L. REV. 1281 (1976). For a description of the widespread use of private attorneys general by both courts and legislatures as an integral part of public enforcement, see Rubenstein, supra note 18, at 2134-36.

120. Erichson, supra note 20, at 39 n.187 (citing Gale A. Norton, The Long Term Implications of Tobacco Litigation 8 (Jan. 8, 2000) (unpublished manuscript) (on file with author)). 
such as standing may prevent purely private lawyers from bringing the precise claims that governments have been litigating in this area, as those who have filed these suits acknowledge the distance between these public actions and the private ones that were already underway was more a matter of form than function. ${ }^{121}$

The real question, therefore, is whether the state should expand its enforcement resources through the use of substitute attorneys general who are specifically deputized for this purpose, or instead rely on what Rubenstein calls supplemental private attorneys general, who he defines as "private attorneys whose work for private clients contributes to the public interest by supplementing the government's enforcement of laws and public policies." 122 Although there are many distinctions between these two roles, one of the most important concerns the degree of control that the public attorney general is able to exercise over the private one. Because they are hired directly by the Attorney General and charged with functioning as if they are members of that office, public officials can - and should - exercise substantial control over the actions of private lawyers acting as substitute attorneys general. ${ }^{123}$ Supplemental attorneys general, who gain their authorization from legislation, rules, or judicial decisions, and who work almost exclusively on their own, are subject to far less direct public control. ${ }^{124}$ To the extent that the criticism we are discussing sounds in democratic accountability, this greater degree of public control should make the former context clearly preferable to the latter.

Of course, as indicated above, to say that public officials can and should exercise significant control over substitute attorneys general does not mean that they will always be able to do so effectively. The critics who raise this issue, therefore, have identified an important issue that bears

121. See id. at 19-20 (quoting the former Attorney General of Colorado as conceding that while " "[i]n a strict legal sense, the state is collecting only its own expenses ... [i]n a less stringent sense, the state is aggregating the claims of its citizens and fulfilling a role similar to that of a class action'"); see also Rubensein, supra note 18, at 2146 (arguing that cases like tobacco constitute a "more private-like function[] than those that constitute the core of the attorney general's work").

122. Rubenstien, supra note 18, at 2146. As Rubenstien acknowledges, these two kinds of private attorneys general are not perfectly interchangeable since the substitute attorney general can bring claims on behalf of the state that are not available to private parties. Id. at 2143-54. Nevertheless, as indicated above, in many instances at the core of what Attorneys General are doing in this area, the claims are very similar.

123. I return to the question of whether that control should be plenary, or whether there are some areas where these private lawyers should retain autonomy, below.

124. See Rubenstein, supra note 18, at 2153 (noting that such lawyers are "clearly not paid . . by [the] government" nor expressly "represents" government interests). This is not to say that public officials currently exercise no control over these lawyers-or that they should not try to exercise more such control. Once again, I will return to these matters below. 
watching. ${ }^{125}$ Where they err, however, is in assuming that the only context in which this issue arises is in situations in which the lawyer is being compensated on the basis of some form of contingent fee.

Many of those who have objected the loudest to the hiring of contingent fee lawyers in this context appear to assume that retaining substitute attorneys general on a flat or hourly fee basis, or enlisting the help of attorneys who will assist the state pro bono, is unproblematic. Indeed, some even go on to assert that engaging private lawyers on anything other than a contingent fee basis is affirmatively beneficial and should be promoted whenever public authorities may need the assistance of the kind of expertise or resources that can best be found in the private sector. ${ }^{126}$ This view, however, severely underestimates the potential conflicts of interest and monitoring issues that can-and often do-arise in both of these other contexts. Thus, as anyone who has studied the legal profession over the last decade is well aware, the very types of large corporations who are being sued in the cases we are now discussing have been trying for years to move away from compensating their own outside counsel on the basis of hourly fees on the ground that it creates a significant incentive for law firms to "run the meter" in a way that is not at all in the interests of their clients. ${ }^{127}$ Although companies have been attempting to cabin this practice for years through ex ante instructions, detailed monitoring of work in progress, and ex post review, many contend that the problem of overcharging and unnecessary work persists. ${ }^{128}$ It is hard to imagine that public authorities who possess both far fewer resources - which, of course, is one of the primary reasons for hiring substitute attorneys general in the first place - and who have far less experience monitoring outside counsel are likely to do a better job. Certainly, the history of government contracting generally provides little indication

125. The fact that a recent "primer" commissioned by the US Chamber of Commerce on defending cases filed by state Attorneys General could not cite to a single instance in which a court had upheld this kind of due process claim, however, suggests that at least to date there is no direct evidence that these legitimate concerns have materialized. See Dickstein Shapiro LlP, Beyond Due Process-A Litigation Primer: Challenging Attorney General and Other Government Contingency Fee Agreements (Jan. 2009) (acknowledging that "courts largely have rejected the argument that government contingency fee arrangements are fundamentally at odds with due process") (on file with author).

126. See, e.g., Erichson, supra note 20 at 35-36 (arguing that "[w] hen private lawyers are hired by the government on an hourly or flat fee, it raises typical outsourcing issues, but need not present major problems of government legal policy" and "[n]or does the government's use of pro bono lawyers"); see also Redish, supra note 53, at 5.

127. See, e.g., Jerry Custis, Litigation Management Handbook $§ 5: 14$ (2009) (stating that in-house counsel have voiced "[m] any . . c criticisms of hourly pricing," including "considerable suspicion that the hourly system encouraged overworking of cases, the assignment of too many lawyers to cases and the spending of time on unimportant or useless tasks," with "no incentive to spend less rather than more time to accomplish tasks").

128. See, e.g., id. 
that public oversight will be particularly effective in this area. ${ }^{129}$ Moreover, although flat fees arguably correct for some of these negative incentives, they increase the danger of others, particularly shirking and other forms of underinvestment. ${ }^{130}$ Once again, it seems doubtful that public authorities will be better at detecting and preventing such conduct than their counterparts in the general counsels' offices of major companies.

The Treasury Department's recent decision to retain thirteen of the country's largest and most prestigious outside law firms to help run the Troubled Assets Relief Program at a potential cost of over $\$ 100$ million underscores just how many of the same issues that arise when substitute counsel are hired on a contingent fee basis are likely to be equally present when the retainer is by the hour. ${ }^{131}$ Notwithstanding the fact that Treasury has almost 2,000 lawyers - making it the equivalent of the fourth largest law firm in the country - the agency has decided it needs outside counsel to assist it with the complex and specialized work that TARP requires. Although Treasury claims that it selected counsel on the basis of a comprehensive bidding process in which the firms had to agree to detailed oversight and evaluation by government officials, both the process itself and the exact terms on which the firms are being hired have not been disclosed-even to the Congressional Oversight Panel that is supposed to oversee the TARP program. ${ }^{132}$ Even the billing rates that the firms will be charging the government for their services "are considered proprietary and will not be provided." 133 Given that these rates are almost certainly many hundreds of dollars an hour - and that the total fees will certainly run into the tens of millions - it is hard to imagine a less democratically accountable process. Clearly, the hourly fee contract in TARP is far less transparent than the contingency fee contract entered into between the State of Nevada and Cohen Milstein discussed above. ${ }^{134}$

129. See, e.g., Jody Freeman, Extending Public Law Norms Through Privatization, 116 HARV. L. REV. 1285, 1317 (2003) (noting that governmental agencies are "generally illequipped" to "extensive[ly] monitor[] private contractors . . not only for cost control and fraud prevention purposes, but also for quality control, which these agencies charged with oversight have traditionally not done very effectively").

130. See, e.g., Wendy Leibowitz, Getting Paid: Is There A Light at the Bottom of the Stack of Bills?, 30 L. PraC. MGMT., May/June 2004, at 22, 22 (describing problems with various legal billing procedures, including "flat fee" arrangements).

131. See Jenna Greene, Cadwalader Biggest Beneficiary as Treasury Adds Firms to Help Run TARP, NAT'L L.J., Oct. 4, 2010, available at http://www.law.com/jsp/article. jsp?id=1202472863561\&src=EMCmail\&et=editorial\&bu=Law.com\&pt=Law.com\%20News wire\%20Update\&cn=LAWCOM_NewswireUpdate_20101004\&kw=Cadwalader\%20Bigges t $\% 20$ Beneficiary $\% 20$ as $\% 20$ Treasury $\% 20$ Adds $\% 20$ Firms $\% 20$ to $\% 20 \mathrm{Help} \% 20$ Run $\% 2$ TARP.

132. Id.

133. Id.

134. See Fee Agreement, supra note 87, $§ 3.3$ (specifying in detail the exact percentage of any recovery that the law firm will receive in particular circumstances). 
Nor is pro bono representation as free from conflict as the critics of contingent fees in this context appear to believe. As Scott Cummings demonstrates, law firms are increasingly viewing pro bono representation through the lens of their broader business and strategic interests. ${ }^{135}$ As a result, these firms are hesitant to participate in any pro bono matter that is likely to upset their current clients - or conflict them out of representing future ones. Given these incentives, it is one thing to find a law firm that is prepared to assist in litigation against gun manufacturers. ${ }^{136}$ It is quite a different matter to find a firm that would be willing to play a significant role in a similar action against mortgage lenders or HMOs. The list of prominent law firms defending lead paint manufacturers cited above suggests that there will be relatively few firms willing to jeopardize their current or future business prospects with these kinds of potentially lucrative clients.

Moreover, even if an Attorney General can find a firm willing to take one of these cases on a pro bono basis, he or she will still have to pay careful attention to ensure that the case is being handled properly. Pro bono cases are often treated as second-class work in many large law firms. The cases tend to be staffed primarily by associates as opposed to partners, and there is a constant danger that the work will be put on the back burner if the lawyer's paying cases heat up. Nor are the lawyers who volunteer to work on these cases likely to be experts in the particular substantive or procedural issues in question. To the contrary, firms tend to use pro bono cases as "training vehicles" for young lawyers to gain the kind of experience that their paying clients are increasingly less willing to pay for. As many a public interest organization has discovered, getting these novices up to speed and making sure that they are working competently and effectively takes a considerable amount of time by the "real" lawyers that these organizations employ full-time. ${ }^{137}$

Finally, lawyers who litigate cases pro bono sometimes appear to believe that they are - or at least ought to be-less bound by their clients' direction and control than would be the case in a fee-for-service relationship. ${ }^{138}$ Needless to say, few would admit to such a view. Nevertheless, the

135. See generally Cummings, supra note 12, at 33-41.

136. Even here, it would be interesting to know how many law firms the City of Chicago asked before finding the ones who agreed to undertake that case - or whether these same firms would do so today.

137. See, e.g., Scott L. Cummings \& Deborah L. Rhode, Managing Pro Bono: Doing Well by Doing Better, 78 FORDHAM L. REV. 2357, 2426-27 (2010).

138. I discuss this possibility in David B. Wilkins, Race, Ethics, and the First Amendment: Should a Black Lawyer Represent the Ku Klux Klan?, 63 GEO. WASH. L. REV. 1030, 1057 (1995) (raising the specter that "when lawyers are not being paid, they have more control over their clients' actions and goals"). 
fact that pro bono lawyers "donate" ${ }^{139}$ their services, and that working on these cases is often touted as giving lawyers an opportunity to express their own interests and commitments in ways that they often do not feel they can do in their paying work, seems likely to promote a feeling of entitlement with respect to influencing the goals to which one's efforts are being directed, at least at a subconscious level. ${ }^{140}$ Once again, state officials will have to monitor for this kind of potential personal or ideological bias when they engage pro bono counsel.

None of this should be taken to suggest that state officials are likely to encounter more problems when they engage substitute private attorneys general on the basis of hourly fees or pro bono representation than they are likely to confront when they proceed - as they have in most cases - to retain such counsel on a contingent fee basis. My point simply is that the distance between these two states of affairs is far less great than the critics of contingent fees in this context suggest.

More generally, my point is that the kind of issues that those who have been critical of the trend toward bringing in private contingent fee lawyers to represent public entities suing private companies are likely to be present in any situation in which private and public lawyering roles are intermingled. As I indicated at the beginning of this Essay, this blurring of boundaries between public and private is becoming increasingly common in the legal profession. I conclude by making a few observations about what the case of the substitute attorneys general can teach us about this more general phenomenon.

\section{TOWARD A NEW MODEL OF THE PUBLIC-PRIVATE LAWYER}

At one level, the case of the private lawyer hired to be a substitute private attorney general might appear to be one of the simplest to resolve from the perspective of sorting through a lawyer's public and private responsibilities. After all, both supporters and critics alike agree that these lawyers are intended to be indistinguishable from their public counterparts. ${ }^{141}$ The only

139. As a partner once reminded me, this characterization is somewhat disingenuous since in most instances the lawyers who are working on these cases are still being paid by the firm to take on this work. As he said with a shrug: "It's pro bono for us not for them!"

140. See generally William H. Simon, The Dark Secret of Progressive Lawyering: A Comment on Poverty Law Scholarship in the Post-Modern, Post-Reagan Era, 48 U. MIAMI L. REV. 1099 (1994) (noting that public interest lawyers will inevitably exert such control but arguing that in the end it is the right thing to do).

141. Compare Redish, supra note 53, at 17 (arguing that "when government delegates the power to litigate claims on the government's behalf to private attorneys, those attorneys are subject to the exact same ethical and political limitations as are full time government attorneys"), with Rubenstein, supra note 18, at 2143 (describing substitute attorneys 
relevant question, therefore, would seem to be how to ensure that the private lawyers who assume these roles carry out their duties in a manner that is fully consistent with the directions of their public lawyer bosses. As we have already seen, however, this simple characterization misses much of the complexity that is actually going on in these relationships. As noted above, many of the criticisms about the hiring of contingent fee lawyers in this setting seem to bemoan the fact that these agents might carry out their principle's wishes too well by helping Attorneys General achieve highly public victories against unpopular companies in order to further their own political gain. Although one might reasonably complain that such actions are not in "the public interest," the fact that publicly elected Attorneys General are likely to see it otherwise suggests that the real problem is not one of agency but instead lies with how the principal is defining his or her public responsibilities to the private parties that are affected by the exercise of state power.

As Howard Erichson demonstrates, this is a pervasive problem in a world in which the actions that public officials take with respect to these cases will have implications that reach far beyond the contours of whatever litigation the state chooses to bring. Given the near certainty that any government lawsuit will produce what Erichson calls "coattail class actions" by private parties, he argues that public lawyers should have an obligation to consider these secondary effects when deciding whether and on what terms to settle their initial litigation. ${ }^{142}$ Specifically, Erichson argues that government lawyers should consider the benefit that private plaintiffs receive from both issue preclusion and access to discovery materials before agreeing to a settlement that would deprive future plaintiffs from the benefit of either. ${ }^{143}$ But as others would surely argue (and as Erichson himself points out in another part of the same article), the defendants are also part of the "public" the government lawyer represents. As a result, government lawyers should also consider whether giving private plaintiffs the benefit of issue preclusion and the public disclosure of discovery material will result in overdeterrence rather than prevent under-deterrence.

Similarly, the private lawyers who are engaged as substitute attorneys general are also likely to have complexly dual commitments-regardless of whether they are retained on an hourly or a contingent fee basis. It is tempting, as William Rubenstein notes, to think of these temporary public lawyers as performing their public and private roles sequentially, as Rubenstein puts it, "private one day, public the next."144 But this characterization ignores the fact that most of the lawyers hired in this position will continue to

general as "literally perform[ing] the exact functions of the attorney general's office"). As indicated above, Redish is far more critical of this practice than Rubenstein.

142. Erichson, supra note 20, at 27-35.

143. Id. at 29-30.

144. Rubenstein, supra note 18, at 2170. 
represent private clients at the same time that they are doing the people's work-and if the lawyer herself does not, then other members of her firm surely will. As a result, these lawyers (or law firms) will be called upon to balance their public and private responsibilities simultaneously as well as sequentially (both before and after their time as a substitute attorneys general is over)..$^{145}$

This duality creates a significant potential for conflicts of interest. In the TARP case, for example, many of the firms hired by the Treasury Department also represent TARP recipients. ${ }^{146}$ Indeed, the firm receiving the lion's share of the work-New York's Cadwalader, Wikersham \& Taftwas widely regarded as one of the leading firms in the country in handling the very credit default swaps, collateralized debt obligations, and other complex financial products that are now being blamed for the collapse. ${ }^{147}$ Not surprisingly, this duality does not sit well with many observers. Thus the Congressional Panel Overseeing TARP asked Cadwalader to disclose its client relationships with TARP recipients so that it could assess the conflict. ${ }^{148}$ Cadwalader and the Treasury Department refused to do so. Instead, both the government and the firm emphasized that Cadwalader was required to provide Treasury with a detailed "conflict-of-interest mitigation plan" that identified "actual, potential or apparent organizational and personal conflicts of interest as part of its proposal." ${ }^{149}$ A senior representative of the firm assured an interviewer that while Cadwalader "has represented TARP recipients on unrelated matters," it "would never represent someone directly in connection with TARP funds" since doing so "would be antithetical to our engagement agreement." 150

Needless to say, one can certainly be skeptical about such promisesespecially since neither the firm nor Treasury was willing to make the exact terms of the engagement public. But even if one is willing to credit the fact that Cadwalader will not represent a TARP recipient in a matter that is "directly adverse" to the firm's duties as substitute attorney general while

145. Rubenstein, borrowing from Robert Cover, calls these two forms of duality "synchronic" and "diachronic." Id. at 2169-70 (citing Robert M. Cover, The Uses of Jurisdictional Redundancy: Interest, Ideology, and Innovation, 22 WM. \& MARY L. REV. 639 (1981)).

146. Greene, supra note 131 (reporting this fact).

147. See Stuart Goldstein \& Angus Duncan, The Developing Global Market for CRE CDOs, ISR, CDO SUPPLEMENT, Mar. 2007, at 10, available at, http://www.cadwalader.com/assets/article/030107DuncanGoldsteinISR.pdf (last visited Oct. 20, 2010) (touting the firm's expertise in complex European CDOs in a paid supplement written by two Cadwalader partners).

148. See Greene, supra note 131 (quoting a member of the panel as complaining that "[t]he panel has requested a comprehensive list of Cadwalader clients that have received TARP funds ... [ [but] [w] have yet to receive that list").

149. Id.

150. Id. 
representing the government, this important restriction does not exhaust the potential for conflict. As a member of the Congressional Oversight Committee accurately observed, "TARP recipients are going to be these firms' clients forever and TARP is going to go away." ${ }^{151}$ The sequential pull of these past loyalties, or the prospect of gaining lucrative business in the future - or both - may cloud the judgment of lawyers at these firms even in the absence of any current direct conflict. ${ }^{152}$

This is not to say that the Treasury Department should not hire Cadwalader or any other firm that has, or might in the future, represent TARP recipients. As a lawyer for another firm that will be part of the Treasury's program conceded, a strict rule prohibiting any such conflicts would mean that "[e]very law firm that's ever represented a bank would have a problem." 153 Given the complexity of the issues that the government is confronting in TARP, it would be counterproductive to prevent Treasury from availing itself of the very representatives most likely to know how to get the job done effectively and efficiently. Indeed, given the rules of vicarious disqualification and the increasing mobility of lawyers both between the public and private sectors and among major law firms, the problem of finding a conflict-free lawyer or firm in this area with the relevant experience that the government needs could be insurmountable. ${ }^{154}$

151. Id.

152. See generally Model Rules of Prof'L CONDUCt R. 1.7(a)(2) (2009) (noting that a conflict can exist when "there is a significant risk that the representation of one or more clients will be materially limited by the lawyer's responsibilities to another client, a former client or a third person or by a personal interest of the lawyer"). In its motion to disqualify Cohen Milstein from representing the State of Nevada in cases involving deceptive mortgage practices, the defendant mortgage company raises a similar argument on the basis of Cohen Milstein's prior representation of a labor union which the defendant alleges has engaged in a concerted campaign against it and other Nevada mortgage lenders. See First Amended Complaint for Declaratory and Injunctive Relief at 15, Lennar Corp. v. Cortez-Masto, No. 1:10-cv-00378-HHK, (D.D.C. Aug. 5, 2010) (arguing that "[t]he harm to Lennar will be immediate and irreparable if outside counsel is permitted to access Lennar's confidential materials and to use whatever it may learn for the benefit of other past, current, or future clients, including Lennar's legal adversaries"). Cohen Milstein denies that it has a conflict on the ground that it resigned from representing the union before undertaking the current public representation. See Nevada Attorney General's Motion to Dismiss Lennar's First Amended Complaint at 27, Lennar Corp. v. Cortez-Masto, No. 1:10-cv-00378-HHK, (D.D.C. Aug. 25, 2010) (citing an acknowledgement by Lennar that the firm withdrew from representing the union several months before the complaint was filed and therefore "dual representation is not occurring and, in fact, never occurred"). As indicated above even if correct, this does not entirely resolve the potential conflict.

153. Greene, supra note 131 (quoting a partner at Haynes \& Boone).

154. See Gina Passarella, Government Lawyers Sought After as Law Firm Laterals, LEGAL INTELLIGENCER, Oct. 4, 2010, available at, http://www.law.com/jsp/article .jsp?id=1202472833973 (last visited Oct. 20, 2010) (reporting that "[i]n a lateral market where books of business typically reign supreme, some law firms have found hiring from the public sector can create business in other ways"). With respect to the rules of vicarious 
The question, therefore, is not how to find a "pure" private lawyer who can serve the public interest free from any potential conflict, but rather how to define the responsibilities of lawyers who are exercising an increasingly complex mix of public and private duties both simultaneously and sequentially. The answer to this question is likely to lie partly in the realm of institutional design. What are the proper checks and balances to insure that private lawyers who are hired as substitute attorneys general, either on a contingent fee as is typically happening at the state level, or on an hourly fee basis as is increasingly prevalent in programs like TARP, serve the public interest when carrying out their official duties and do not use information or other resources that they obtained in their official capacity to unfairly disadvantage some citizens or advantage others once they return to their "private" practices? Should the private lawyers who serve in this public capacity be viewed as independent contractors whose rights and obligations are primarily a matter of contract? Or should they be considered quasi employees who are subject to the same rules of ethics and conflicts of interest as the public officials for whom they act as surrogates? ${ }^{155}$ Engaging with scholars who think about the proper design and functioning of public institutions will be essential to answering these and other perplexing questions. ${ }^{156}$ Given the enormous expansion in the use of government contractors and other similar means of providing public services through private parties, ${ }^{157}$ this is a conversation that needs to begin immediately.

disqualification, see MOdel RULES OF PROF'L CONDUCT R. 1.10 (2009) (describing the rules governing lawyers moving from one private law firm to another) and MODEL RULES OF PROF'L CONDUCT R. 1.11 (describing the rules applicable to lawyers moving in and out of government). I return to the shrinking difference between these two rules below.

155. See Clark, supra note 11 , at 4 (reporting that " $[\mathrm{m}]$ ost of the ethics statutes and rules that regulate government employee ethics do not apply to contractor personnel"). Indeed, as Clark notes in another piece, TARP differentiates between the fiduciary and disclosure obligations of law firms such as Cadwalader, which are classified as "contractors," and "fiduciary agents" that TARP hires to manage its assets, who are expressly required to "agree[] to act at all times in the best interests of the United States." Kathleen Clark, Fiduciary-Based Standards for Bailout Contractors: What Treasury Got Right and Wrong in TARP (Feb. 2, 2011) (unpublished manuscript on file with the author), at 8 . For an excellent discussion about the increasingly complex relationship between the public and private spheres, see Martha Minow, Partners, Not Rivals: Privatization and the Public GOOD (2002).

156. For a thoughtful analysis that attempts to begin a conversation between those who study professions and theorists of public institutions in a related context, see Adrian Vermeule, Second Opinions and Institutional Design (2010) (unpublished manuscript) (on file with author and available at http://papers.ssrn.com/sol3/papers.cfm?abstract_id= 1646414) (linking the professional literature on second opinions with a political theory analysis of the design of public institutions).

157. Kathleen Clark estimates that between 1983 and 2007, the amount of government service contracting grew by $85 \%$ in constant dollars from $\$ 70$ billion to $\$ 130$ billion ( $\$ 268$ billion in today's terms). Kathleen Clark, Financial Conflicts of Interest In and Out of 
In the last analysis, however, addressing this new reality is likely to be as much a matter of ethics and identity as structures and rules. As William Rubenstein concludes, we must first determine how much a given private attorney general should be "an agent for public ends, in addition to private ones" before we can determine the "rules by which we should enable (and constrain) her and the fees with which we should reward her." 158

Ironically, the legal profession used to have a fairly simple and straightforward way of thinking about this question. Lawyers, according to this traditional view, are simultaneously and indivisibly both zealous advocates for the interests of their private clients and officers of the legal system with a special obligation to protect democratic values and the rule of law. ${ }^{159}$ Given this ethos, it is not surprising that elite lawyers in the "Golden Age" 160 of the large law firm in the middle decades of the twentieth century drew relatively little distinction between their work for private clients and their occasional service in the public arena. As Erwin Smigel reported in his study of Wall Street lawyers in the 1960s:

Such partnerships are likely in the future, as they have in the past, to prepare and offer for public service men exceptionally qualified to serve. The very nature of such a partnership permits a man to do more, not less civic work, and permits him, as a true officer of the court and a responsible citizen, more readily to enter public service for various periods and to serve society to his full professional capacity. ${ }^{161}$

Today, such confident pronouncements about the seamless and mutually reinforcing connection between private practice and public service ring hollow against the backdrop of the increasingly competitive and cutthroat global market for legal services. There is a widespread feeling among younger and older lawyers alike that the once interconnected worlds of private practice and public service have grown increasingly distant from each

Government (Feb. 2, 2011) (unpublished manuscript on file with the author forthcoming in the Alabama Law Review), at 9-10.

158. Rubenstein, supra note 18 , at 2173 . Rubenstein uses a distinctly personal analogy to drive this point home. Id. at 2172 (analogizing the mix of public and private duties of various private attorneys general to the mix of heterosexual and homosexual impulses that make up an individual's unique sexuality).

159. I elaborate this traditional claim in David B. Wilkins, Legal Realism for Lawyers, 104 HARV. L. REV. 468, 470-71 (1990).

160. As Marc Galanter has been quick to remind us, these often celebrated days were not particularly "golden" for the many groups who were excluded from law firms - or indeed the legal profession altogether. See Marc Galanter, Lawyers in the Mist: The Golden Age of Legal Nostalgia, 100 DiCK. L. REV. 549 (1996). For my own take on this kind of golden age rhetoric, see David B. Wilkins, Practical Wisdom for Practicing Lawyers: Separating Ideals from Ideology in Legal Ethics, 108 HARV. L. REV. 458 (1994) (reviewing ANTHONY T. Kronman, The Lost Lawyer: Failing Ideals of the Legal Profession (1995), which makes several approving references to the golden age).

161. ERWin O. SMigel, The Wall Street LaWyer: Professional Organizational Man? 8-9 (Ind. Univ. Press 1973) (1969). 
other, with lawyers and even law students forced to stake their claim to one or the other realm at an ever earlier time. ${ }^{162}$ And yet, the series of connected trends discussed at the outset of this Essay point to a more complex reality. Public and private roles are arguably more inextricably intertwined than they have been at any other time in the profession's history. Although it is unlikely that the profession could ever recreate the ethic of seamless integration that it purported to maintain during the "Golden Age"163 — and it is far from clear that it would be desirable to do so even if turning back the clock in this fashion were indeed possible-it does seem necessary to move away from the current understanding that tends to separate public and private interests into distinct and largely insular camps.

As I said at the outset, defining exactly what such an ethic would look like is far beyond the scope of this Essay. Nevertheless, the above analysis suggests three dimensions along which the task of articulating a new synthesis should proceed. First, at a minimum lawyers need to be taught to recognize and appreciate the various public and private dimensions of their particular roles. This process must go beyond the "Golden Age's" simple sloganeering that a lawyer is always and indivisibly an "advocate" for the private interests of clients and an "officer of the court" responsible for protecting the public purposes of the legal framework. Although as I have argued elsewhere, there is an important truth wrapped inside this standard bromide, ${ }^{164}$ this characterization does not help lawyers to distinguish which public or private responsibilities attach to particular lawyering roles, nor how practitioners (or policymakers) should resolve the inevitable conflicts that arise when these two sets of responsibilities pull in different directions. What is needed, therefore, is a much more specific articulation of the nature of a lawyer's public and private duties in particular contexts and an exami-

162. David B. Wilkins, Doing Well by Doing Good? The Role of Public Service in the Careers of Black Corporate Lawyers, 41 Hous. L. REv. 1, 3-7 (2004) (describing this growing separation); see also Deborah L. Rhode, The Professionalism Problem, 39 WM. \& MARY L. REV. 283, 297-98, 300 (1998) (noting a reduction in public service among lawyers and reporting that three quarters of bar members surveyed believe that lawyers are increasingly money conscious).

163. Of course, whether the profession ever really lived up to its stated creed is debatable to say the least. See Robert W. Gordon, "The Ideal and the Actual in the Law": Fantasies and Practices of New York City Lawyers, 1870-1910, in THE NEw High PrIESTS: LAWYERS IN POST-CIVIL WAR AMERICA 51 (Gerard W. Gawalt ed., 1984) (arguing that notwithstanding all of its many faults, that elite lawyers in the late nineteenth and early twentieth centuries did at least take seriously their commitments to public service both within and outside their roles as private lawyers).

164. See David B. Wilkins, Partner Shamartner! EEOC v. Sidley Austin Brown \& Wood, 120 HARV. L. REV. 1264, 1273-77 (2007) (discussing the "paradox of professional distinctiveness" which posits that a plausible connection to public purposes and goals is one of the key things that makes the legal profession distinctive and helps to preserve its autonomy and prestige). 
nation of the institutional incentives and constraints that either contribute to exacerbating the tension between these responsibilities or that might be enlisted to reduce this tension. ${ }^{165}$

Thus, it is not sufficient to tell plaintiffs' lawyers serving as substitute attorneys general that they should behave as if they were government lawyers. Notwithstanding the fact that they have been deputized to serve as public officials, these lawyers nevertheless remain private practitioners subject to the incentives created by their law firms and by the private marketplace generally. Given their position, it is not only inevitable but completely appropriate for these lawyers to care about being compensated for the work that they perform and their law firm's continuing ability to compete in the marketplace. The question, therefore, is not whether these privatepublic lawyers will be motivated in part by their own financial interests. Indeed, it is precisely the desire to harness these market-based incentives that have led many public actors to favor privatizing various public functions in the first place. ${ }^{166}$ Instead, the relevant question is the extent to which substitute counsel should be entitled to act on these motivations, and whether institutional and procedural mechanisms can be put in place by both public and private actors to keep these incentives within reasonable bounds.

Overall, the kind of contract exemplified by the agreement between Cohen Milstein and the state of Nevada appears to do a pretty good job of balancing these competing considerations. As indicated above, the agreement gives the Attorney General the right to control all major elements of the litigation, including whether and on what terms the case will be settled. There is, however, one exception to the Attorney General's plenary authority in this area. In the event of a settlement "for injunctive relief only" (or other terms that provide relief directly to borrowers in the form of favorable future terms), the contract provides that Cohen and Milstein will receive "costs and hourly fees at fair market value of their legal services expended on behalf of the State."167 "In such an event," the contract continues, "the State agrees not to settle the case unless the defendant agrees to pay said amount." 168 This provision is meant to protect Cohen and Milstein from socalled "sacrifice" offers in which the defendant agrees to provide certain

165. For my prior arguments in favor of a more context-specific approach to legal ethics, see, for example, Wilkins, supra note 8; David B. Wilkins, Who Should Regulate Lawyers?, 105 HARV. L. REV. 799 (1992); Wilkins, supra note 159. I return to the issue of regulation below.

166. See Minow, supra note 155, at 25-27 (discussing market based justifications for privatization).

167. Fee Agreement, supra note 87, § 3.5.4.

168. Id. 
injunctive relief in return for the plaintiff agreeing to waive any claim for attorney's fees. ${ }^{169}$

In Evans v. Jeff D., the Supreme Court approved the defendant's use of such offers over the strenuous objection of many members of the public interest bar who claimed that allowing defendants to demand fee waivers would diminish the enforcement of the civil rights laws. ${ }^{170}$ In reaching this conclusion, however, the court endorsed the negotiability of fee waivers more generally, suggesting that there was nothing to prevent lawyers from entering into agreements with their clients to refuse such offers ex ante, or to provide that accepting such a settlement would trigger an obligation by the plaintiff to pay the lawyer from other sources. ${ }^{171}$ Consequently, Cohen Milstein would arguably be entitled to insist on inserting a provision preventing a fee waiver in its retainer agreement with one of its private clients. In the context of this kind of public representation, however, this kind of contract provision can legitimately be seen as a restriction on the state's plenary power to settle the case without respect to Cohen Milstein's interests.

The fact that the State of Nevada has agreed not to accept a pure sacrifice offer to settle the case, however, does not mean that the Attorney General has exceeded her authority in agreeing to this term. To be sure, if the state were represented solely by public lawyers, it would be able to settle the case on any terms the Attorney General saw fit, including terms that precluded the state from seeking payment for its attorneys fees. But the state has chosen to seek the benefit of engaging private lawyers to help it pursue its claim. As private practitioners, Cohen Milstein cannot stay in business unless it is paid for its work. While the firm might decide to donate its services to the state pro bono, it is not required to do so. It therefore should have the right to protect itself against opportunism by both defendants and state officials in crafting a settlement that essentially forces the firm to donate its services, even if the practical effect of this provision is to make it more difficult to settle the case. Although many would argue that preventing settlements conditioned on fee waivers promotes the public in-

169. 2 Martin A. Schwartz \& John E. Kirklin, Section 1983 Litigation: StAtutory Attorneys FeEs 441 (Aspen Law \& Business 3d ed. 1997) (defining a sacrifice offer as an offer in which "the defendant expressly conditions the granting of substantial relief, often of an equitable nature, on the plaintiff's waiver or severe compromise of the right to statutory attorney's fees on which plaintiff's counsel is wholly or partly relying for the payment of his fee").

170. See 475 U.S. 717, 730-38 (1986).

171. Id.; see also Moore v. Nat'l Assn. of Sec. Dealers, Inc., 762 F. 2d 1093, 1105 (D.C. Cir. 1985) (specifically noting that "carefully drafted retainer agreements" between plaintiffs and their attorneys could "minimize the potential conflicts" between plaintiffs' attorneys and their clients with respect to possible fee waivers resulting from settlement negotiations with defendants). 
terest, ${ }^{172}$ even if it is only in the narrow economic self-interest of Cohen Milstein the firm should nevertheless be entitled to insist that it will only go forward with the representation if the state agrees to forgo this potentially beneficial option. ${ }^{173}$ If the Attorney General believes that this is too much of an imposition on the public interest, he or she can always try to find another private firm that will not insist on this provision, or prosecute the action with public attorneys over whom the state can exercise plenary control.

By the same token, the public lawyers working with Cohen Milstein ought to be entitled to insist on certain restrictions on conduct within the firm that in the private context would be considered perfectly appropriate in order to preserve the state's legitimate public interest in the representation. The contract between the state and the firm indeed does provide many such restrictions. As indicated above, the contract lays out in great detail Cohen Milstein's obligation to litigate the case in a manner that allows the Attorney General to ensure that the public's interest is protected - as the Attorney General defines these goals. ${ }^{174}$ The agreement also requires the firm to adhere to restrictions regarding conflicts of interest that arguably go beyond what would be required in the private context. Thus, Cohen Milstein must "advise the Attorney General of any perceived conflict . . . throughout the performance of this Contract" and is prevented from "engage[ing] in private litigation against the State at the same time [that the firm] accepts appointments representing the State" pursuant to the contract without the government's express consent. ${ }^{175}$ Finally, Cohen Milstein agrees that its "books, records, documents and accounting procedures" relevant to the firm's performance under the contract "shall be subject to inspection, examination and audit by the State." ${ }^{176}$

172. See generally Margaret Annabel de Lisser, Comment, Giving Substance to the Bad Faith Exception of Evans v. Jeff D.: A Reconciliation of Evans with the Civil Rights Attorney's Fees Awards Act of 1976, 136 U. PA. L. REV. 553 (1987) (arguing that Evans was inconsistent with the spirit of the fees act).

173. Given that the firm would have done nothing wrong in a situation where the defendant makes a "sacrifice" offer-and will have procured injunctive or other nonmonetary relief for the state- this kind of provision is qualitatively different from ones that attempt to restrict the state's plenary right to control the case by requiring that substitute counsel be paid a large percentage of any future recovery even after it has been dismissed for cause or that require outside counsels' approval before the Attorney General can accept a monetary settlement. See DicKSTEIN SHAPIRO, supra note 125, at 6-7 (reporting courts that have questioned these provisions).

174. Once again, whether this is really protecting the public interest is a function of the Attorney General's political motivations - and the ability of other state officials and the public at large to check these incentives.

175. Fee Agreement, supra note 87, $\S \S 16.1,16.2$.

176. Id. § 24 . 
These restrictions, however, should arguably extend beyond the four corners of the representation itself. Concurrent conflicts, in which a law firm like Cohen Milstein is simultaneously representing a client with interests opposed to the state at the same time it is acting as substitute attorney general, are only one of the potential risks to the public interest in these cases. As the TARP example underscores, there is also the danger that private firms in this role will be influenced by their past client relationships, or the possibility of representing clients in the future. Although the Model Rules of Professional Responsibility applicable to all lawyers provide some protection against these kind of former (or future) client conflicts, ${ }^{177}$ the fact that substitute attorneys general are also discharging public responsibilities counsels in favor of state officials requiring firms like Cohen Milstein to disclose past client relationships that have been adverse to the state as well as those that are currently ongoing. ${ }^{178}$

Indeed, once we acknowledge that defendants are also part of the "public" that both the public and private lawyers in these cases are obligated to protect, it is clear that contractual provisions requiring firms like Cohen Milstein to make certain representations and disclosures to state officials may not be enough to protect these third parties' interests. To address these concerns, we must move beyond the realm of private contracting to examine how public law can help to ensure a proper balance between public and private responsibilities in cases of this kind.

At a minimum, the "pay-to-play" risks associated with private lawyers vying for potentially lucrative appointments as substitute attorneys general underscores the need for both state and federal authorities to ensure that such engagements are subject to statutes or regulations requiring transparency and open procedures. Similarly, to the extent that these private lawyers are being deputized to operate as if they are officers of the state, they should be subject to the public regulations that govern the conduct of public employees.

Consider, once again, the conflict rules. The Model Rules of Professional Responsibility have always contained special rules regulating conflicts of interest for government lawyers. ${ }^{179}$ These rules restrict the ability of former government lawyers to represent private clients in matters in which

177. See Model Rules of Prof'L Conduct R. 1.7 (a)(2) (2009) (prohibiting lawyers from representing clients where there is a significant risk that their judgment will be compromised by their representation of a former client or by the interests of a third person or by the personal interests of the lawyer); see also Model Rules of PROF'L CONDUCt R. 1.9 (relating to conflicts involving former clients).

178. Fee Agreement, supra note 87, $\S 16.2$ (requiring disclosure of "all litigation, claims and maters in which Contractor represents parties adverse to the State") (emphasis added).

179. Model Rules of Prof'l Conduct R. 1.11 (entitled "Special Conflicts of Interest for Former and Current Government Officers and Employees"). 
[Vol. 2010:423

the lawyer "participated personally and substantially as a public officer or employee" and restrict current government attorneys from "participat[ing] in a matter in which the lawyer participated personally and substantially while in private practice." ${ }^{180}$ As the comment to the Rule states, these provisions are designed not only to protect the interests of former clients but also "to prevent a lawyer from exploiting public office for the advantage of another client." 181 As indicated above, one of the risks associated with bringing in private lawyers to act as substitute attorneys general is that they will use this position to further the interests of other past, present, or future clients - either by subsequently bringing "coattail litigation" against similar defendants in cases like the Tobacco Litigation, or in the TARP area, by steering government policy in favor of financial institutions that may have been former clients (or which may one day be future clients). Yet it is not clear that the law firms engaged as substitute attorneys general in these cases are covered by these restrictions. The agreement between Cohen Milstein and the State of Nevada, for example, expressly provides that the firm is being hired as an "independent contractor" and "shall not be deemed officers, agents or employees of the State of Nevada." 182 Given that these firms are supposed to act as if they are simply just another public lawyer for the state, however, it is hard to see why the legal distinction between an "officer or employee" on the one hand and an "independent contractor" on the other should exempt them from these regulatory prohibitions. ${ }^{183}$

Indeed, one can make an argument that the special dangers inherent in this kind of representation counsel in favor of providing more protection to affected third parties than is currently provided in Model Rule 1.11. As currently drafted, the Rule allows a former government lawyer to represent a private client in a case in which he or she participated personally and substantially while in government - or a current government lawyer to participate in a matter in which he or she had the same kind of involvement on behalf of a former client while in private practice-so long as "the appropriate government agency gives its informed consent, confirmed in writing." 184 Although this requirement arguably protects the government's in-

180. Id. R. 1.11(a)(2), (d)(2)(i).

181. Id. R. $1.11 \mathrm{cmt} .3$.

182. Fee Agreement, supra note 87, § 20. As indicated above, the lawyers who are hired under the TARP program are similarly treated as "contractors" and not "financial agents." See Clark, What Treasury Got Right, supra note 155.

183. Kathleen Clark makes a similar argument with respect to independent contractors performing government functions generally. See Clark, supra note 11 (arguing that independent contractors should be subject to the same restrictions on conflicts of interest as government employees).

184. See Model Rules of Prof’l Conduct R. 1.11(a)(2), (d)(2)(i). 
terest, ${ }^{185}$ it may not be sufficient to protect the interest of private parties who may also be affected by whether these substitute attorneys general are properly weighing their public and private responsibilities, both while acting in this capacity and after they return to private practice. To be sure, there are certainly valid reasons for not requiring all such affected parties to give their express consent in every case where a lawyer is moving from government to private practice or vice versa. It does, however, make sense to require government officials to disclose publicly in such cases that they have given their consent, along with a description of whatever safeguards have been put in place, so that private parties can challenge whether the decision is consistent with a broad understanding of the public interest that includes their interests as well.

A similar analysis should apply to the restrictions regarding the use of confidential information that a substitute attorney general learns in the course of her representation. The contract between Cohen Milstein and the State of Nevada expressly recognizes the danger that the firm's acquisition of this kind of information can pose for third parties. Thus, the firm is required to use any "confidential business information" that it learns in the course of the representation "only for the purposes of carrying out the work required by the Contract" and may not disclose the information "to anyone other than properly cleared employees" and must return all such information to the Attorney General "whenever the information is no longer required . . . for performance of the work . . . or upon completion/termination of the Contract." 186 These restrictions, however, are not nearly as protective of the interests of third parties as those provided for in Model Rule 1.11 with respect to government officers or employees. That Rule flatly provides that

a lawyer having information that the lawyer knows is confidential government information about a person acquired when the lawyer was a public officer or employee, may not represent a private client whose interests are adverse to that person in a matter in which the information could be used to the material disadvantage of that person. ${ }^{187}$

185. Congress appears to have reached a different conclusion. Unlike the Model Rules, federal law prohibits federal agencies from consenting to such representation, at least in circumstances where the former government lawyer would make an appearance in federal court or communicate with the government on behalf of a client. See 18 U.S.C. § 207(a). I am grateful to Kathleen Clark for bringing this statute to my attention.

186. Fee Agreement, supra note 87, §§17-3.

187. Model Rules of Prof'L Conduct R. 1.1(c). The Rule goes on to define "confidential government information" as "information that has been obtained under governmental authority and which, at the time this Rule is applied, the government is prohibited by law from disclosing to the public or has a legal privilege not to disclose and which is not otherwise available to the public." Id. It is likely that a significant amount of the information that private lawyers acting as substitute attorneys general learn during the course of litigation against private clients would fit this definition. 
The Rule goes on to provide that other lawyers in the firm may only handle such a matter if "the disqualified lawyer is timely screened from any participation in the matter and is apportioned no part of the fee therefrom." ${ }^{188}$ Once again, given that substitute attorneys general are supposed to be indistinguishable from their public counterparts, there seems little reason to exempt them from these requirements simply because they are technically independent contractors and not government officers or employees.

Indeed, here too one might argue that the rules should go even further in this context to ensure that affected private parties receive notice and an opportunity to be heard to protect their interests. In a move that itself highlights the shrinking distance between public and private lawyers, the Model Rules were recently amended to allow law firms hiring lawyers moving from one private law firm to another to engage in the kind of screening that previously had only been permitted when lawyers moved from government employment to the private sector. ${ }^{189}$ In order to ensure that former clients are able to protect their interests in these circumstances, the Rule requires that any firm seeking to set up such a screen provide written notice to "any affected former client," including "a description of the screening procedures employed; a statement of the firm's and of the screened lawyer's compliance with these Rules; a statement that review may be available before a tribunal; and an agreement by the firm to respond promptly to any written inquiries or objections" as well as periodic certifications during and after the case. ${ }^{190}$ Although these requirements only apply to "former clients," a similar set of disclosure and reporting obligations to inform parties who may be affected by the screening of a lawyer who is or has acted as a substitute attorney general in a matter in which that attorney has learned confidential information that may be relevant to a matter being litigated by other lawyers in the firm would serve similar purposes.

Although there are, therefore, persuasive arguments for holding substitute attorneys general to the same rules regarding conflicts of interest that apply to government lawyers in general, and perhaps in some circumstances rules that are even more stringent, these same rules caution against making these restrictions so stringent that they discourage lawyers from serving in this role. As the Comment to Model Rule 1.11 makes clear, "the rules governing lawyers presently or formerly employed by a government agency should not be so restrictive as to inhibit transfer of employment to and from the government." 191 This is particularly important in this context since not-

188. Id. R. 1.11(b).

189. Id. R. 1.10(a)(2).

190. Id.

191. Id. R. 1.11, cmt. 4. Cf. Clark, supra note 10, at 1065-66 (noting that "[b]ecause the lawyer-client relationship is different [in the public context], the state attorney general is 
withstanding their duty to act as if they are just another lawyer for the state, substitute attorneys general remain, as I have argued above, private lawyers who are entitled to respond to the incentives of the private marketplace. Moreover, as the description of the differences between Motley Rice and Cohen Milstein outlined above underscore, there are benefits as well as risks associated with having former government lawyers engaged in this kind of public-private representation. This brings us to the third and final factor that should shape our understanding of how to balance these two increasingly intertwined but nevertheless conflicting aspects of the lawyer's role: mobility.

As I indicated at the outset of this Essay, a growing number of lawyers are building careers that move between the public and the private sector. Indeed, even the Eternal General Frank Kelley returned to the private sector after completing his thirty-seven years in office, building one of the most successful lobbying firms in the state. ${ }^{192}$ This revolving door clearly creates risks, in the language quoted above from the Model Rules, that lawyers will "exploit" the benefits of public office for the advantages of private clients. But it also creates a cadre of private lawyers who understand the benefits of public service, and public lawyers who know what it is like to be on the receiving end of public power. To be sure, there is no guarantee that these lessons will be used to bring these two domains closer together. But just as those who support mandatory pro bono programs and other forms of public service in law school have argued that being socialized into the culture of public service at an early age will affect the way that this new generation of lawyers understand and act on the public dimensions of their roles as private practitioners, there is at least the possibility that spending time in multiple areas of practice will give those who do so a greater appreciation of the legitimate (and illegitimate) interests and concerns of, for example, public officials even as they represent private clients. ${ }^{193}$ Reports about the culture and standards of the community of former Assistant United States Attorneys who have moved into private practice suggest that in at least some circumstances these hopes can be realized. ${ }^{194}$ The fact that firms such as Cohen

permitted to do things that conflict-of-interest standards would normally prohibit" such as representing two state agencies opposing each other in a law suit).

192. See Kelley CAWTHORNE, http://www.kelley-cawthorne.com/index.html (reporting that Mr. Kelley founded the firm in 1999 and that it has "quickly distinguished itself by being named as one of the state's top five (5) most effective lobbying organizations").

193. See Robert Granfield \& Philip Veliz, Good Lawyering and Lawyering for the Good: Lawyers' Reflections on Mandatory Pro Bono in Law School, in PRIVATE LAWYERS \& the Public Interest: The Evolving Role of Pro Bono 53 (Robert Granfield \& Lynn Mather, eds. 2009) (making this argument).

194. I and others have written generally about the unique culture and community of former AUSAs in a variety of contexts. See, e.g., Wilkins, supra note 162, at 43-44 (referring to the "former assistant's club' of ex-AUSAs" in private practice that helped AUSA 
[Vol. 2010:423

Milstein are developing government-representation practices that are largely staffed by former government lawyers, therefore, should be taken as a hopeful sign.

Needless to say, it remains to be seen whether any of these three strategies - educating lawyers about the need to consider and address the specific tensions created by the tug of public and private considerations in particular lawyering contexts, crafting ethical and regulatory policies that seek to shape and constrain these tensions, or encouraging professional socialization that takes advantage of the growing movement of lawyers between public and private settings - will create a new and workable way of conceptualizing and managing the public-private distinction in legal ethics. What is certain is that we are unlikely to make progress unless we find a way of talking about this issue that goes beyond both the traditional model's assumption that there is in fact no tension between these two roles and the more recent tendency to talk as if these two domains are irreconcilable and mutually exclusive. The growing use of substitute attorneys general at both the state and federal levels and the complex issues this practice poses for both governments and private parties underscores that we delay moving beyond these standard hobby horses at our peril.

Angela Dawson secure a job in the white collar defense bar, and emphasizing that Dawson specifically chose a firm with "a larger number of former AUSAs who could help ease her transition"); Ellen Yaroshefsky, Cooperation with Federal Prosecutors: Experiences of Truth Telling and Embellishment, 68 Fordham L. Rev. 917, 931-63 (1999) (describing interviews with former AUSAs that revealed strong consensus on many important issues involving the cooperation process and role of cooperators in criminal cases). 